\title{
Inmigrantes judíos húngaros en México: dilemas identitarios
}

Hungarian jewish inmigrants in Mexico: identitarian dilemmas

Frida Staropolsky-Shwartz fshwartz@prodigy.net.mx

UNAM

México

\section{Resumen}

La singular identidad de los judíos húngaros que llegaron a México desde las primeras décadas y mediados del siglo XX, muestra una gama de referentes identitarios que refleja posturas subjetivas respecto a su sentir, identificaciones y pertenencias. Las complejas situaciones de sus experiencias personales, familiares y como grupo judío, en diferentes épocas, fueron marcadas por las disyuntivas que les generaron una tensión permanente entre ser y pertenecer como ciudadanos y como judíos. Testigos de escenarios violentos, de exclusión más que de inclusión societaria en Hungría, tuvieron la oportunidad posteriormente de llegar a México como un espacio de sobrevivencia, residencia y permanencia. Se analizan cualitativamente diversas problemáticas identitarias con base en las historias de vida de catorce de los treinta y tres casos de estos inmigrantes húngaros judíos que formaron parte de una investigación sobre el tema llevada a cabo entre 2005 y 2012.

Palabras clave: Identidades judíos húngaros - pertenencias - migraciones - etnicidad nacionalismo - exclusión - inclusión.

\section{Abstract}

The unique character of hungarian jews that came to Mexico in the first half of the Twentieth Century, show a range of identity referents reflecting subjective positions regarding their feel, identification and belonging. The complex situations derived through 
time from experiences on a personal, family and jewish community level, where marked by dilemmas created by an ongoing tension between being Jews and belonging as citizens. Witnesses to violent scenarios, more of exclusion than inclusion from Hungarian society, they found in Mexico a space of survival, residence and permanence. Different identity problems are analyzed qualitatively, based on the life stories of fourteen hungarian jewish immigrants, that were part of a thirty two case research done between 2005 and 2012.

Key words: Jewish Hungarian Identities - Sense of belonging - migrations - ethnicity nationalism - exclusion - inclusion.

Los judíos húngaros en México, dentro del espectro de migrantes, mantienen una identidad singular en la que se confrontaron con el alto grado de nacionalismo húngaro, que aún les brinda raigambre, con la frustración de no haber logrado esa pertenencia nacional a la que apelaron con tanto empeño. Dispuestos a asimilarse a la lengua, la cultura y la idiosincrasia húngara, inclusive cambiando sus nombres y marginando su judeidad, vivieron en su mayoría en Budapest siendo partícipes de las transformaciones políticas y económicas de su país, de las revoluciones políticas e ideológicas que acontecieron como resultado de la Primera Guerra Mundial. Como una paradoja del destino, el empeño por pertenecer no logró amainar el antisemitismo reinante que se acrecentó con las ideologías y las transformaciones geopolíticas y económicas de entre guerras, durante la Shoá y posteriormente de la Segunda Guerra Mundial, negándoles la posibilidad de ser húngaros plenos e integrados a la sociedad de origen. Este extrañamiento fue el amenazante desafío que los obligó a buscar otros derroteros para sobrevivir y desarrollarse, y determinó su porvenir y trayectoria en los países que los acogieron.

En el caso de quienes llegaron a México a partir de 1920 y hasta después de la Segunda Guerra Mundial —unos como consecuencia del nazismo, otros del comunismo- es común ver variadas posturas: visiones chauvinistas de Hungría, afinidades socialistas o 
de derecha, inclusive algunas tendencias a la religiosidad, desde el secularismo hasta una marcada ortodoxia. La actitud con respecto a México está ceñida a las circunstancias en las que llegaron y a las experiencias que les ofreció como espacio de sobrevivencia, de residencia y permanencia.

Cabe preguntarse: ¿Cómo atraviesa de manera significativa lo judío — su ser y pertenecer- en las identidades de algunos migrantes judíos húngaros que llegaron a México? ¿Cómo determinaron su identidad cada uno de los contextos donde vivieron, se movilizaron y se asentaron? ¿Qué determinó esas experiencias de inserción, inclusión e integración, o bien de rechazo, exclusión y violencia?

Es bien conocido que el despertar de la modernidad y el surgimiento de los EstadoNación en Europa, problematizó las controversias identitarias entre religiosidad y nacionalismo. Por un lado, implicó acceder a una condición civil como individuo, con derechos y obligaciones y, por el otro, mantener una etnicidad: ser judío, parte de un grupo diferenciado. La modernidad judía también confrontó de manera crítica los patrones y las tendencias construidos y consolidados desde la época del medioevo con la Kehilá (comunidad) como entidad rectora - autoridad que delimitaba su entorno con una cosmovisión halájica (acorde a la ley religiosa judía). La condición moderna judía fue una ruptura: cuestionó, replanteó y generó posturas y acciones paradójicas y tensionales entre ser y dejar de ser. Redefinió las relaciones entre el individuo y la comunidad, entre la tradición y nuevas formas de adquirir una identidad personal y colectiva, entre las comunidades judías y las sociedades circundantes (Judit Bokser, 2013).

Los procesos de diferenciación e individualización afectaron los vínculos de algunos sectores del mundo judío al generar fuertes controversias entre mantener una identidad adscrita, fundamentada en la normatividad de lo heredado y en la tradición, o transformar su condición judía como electiva y convertirla en un asunto opcional: ser judío o no serlo en lo absoluto. ¿Fue una condición polarizada o estuvo matizada dependiendo de las 
circunstancias? ¿Qué tipos de circunstancias se les planteó en ese sentido a los sujetos de nuestra investigación en cuestión de definirse, identificarse, pertenecer?

Este artículo, producto de una investigación ${ }^{1}$ cualitativa basado en historias de vida, reconstruye la memoria histórica de los judíos húngaros que inmigraron a México. El objetivo central fue la reconstrucción biográfica de sus historias de vida, sus trayectorias migratorias y su inserción en la sociedad mexicana a lo largo del siglo XX. A partir del análisis sociológico se vinculan las historias personales de los inmigrantes con los procesos de construcción de identidades comunitarias y nacionales. La aproximación metodológica se centró en entrevistas autobiográficas a los inmigrantes húngaros, realizadas entre 2005 y 2010, y en el caso de quienes habían fallecido se reconstruyeron sus vidas con la información aportada por sus descendientes. Ello se complementó con un breve análisis de las características de las personas de origen húngaro o hablantes de lengua húngara y sus descendientes entrevistados en la encuesta representativa de la población judía de la ciudad de México realizada por El Colegio de México y la Universidad Hebrea de Jerusalén en 1991. (DellaPergola S., Lerner, S.,1995).

El contexto histórico, es decir las constantes y variadas transiciones políticas, económicas y socioculturales en Hungría, determinó las complejas situaciones personales y colectivas, las diferentes nociones de ciudadanía, el estigma y la discriminación que prevaleció a pesar de la magyarización —una exigencia para homogeneizar culturalmente a la sociedad promoviendo el abandono de las identidades comunitarias y étnicas para aspirar a una pertenencia nacional. En el caso de los judíos esta homogeneidad cultural y lingüística fue una paradoja porque si bien ellos intentaron desdibujarse para ser "ciudadanos húngaros", es decir ceder y borrar todo vestigio de su identidad étnica, la sociedad no los aceptó como tales.

\footnotetext{
${ }^{1}$ Migración e identidades: la inmigración de judíos húngaros a México durante el siglo XX, realizada en 2007 por Ivonne Szas y Frida Staropolsky, COLMEX-CONACYT. 
Con la emergencia del nacionalismo, surgió un discurso antisemita que enfatizó la imagen del judío como "extranjero" e "intruso", mismo que aún se mantiene en Hungría, que los obligó a emigrar al ser testigos de escenarios violentos y de un contexto de exclusión societaria, más que de inclusión. Cabe mencionar que algunos, por haber migrado siendo muy pequeños o por haber tenido una situación socioeconómica favorable, no padecieron de manera directa esa experiencia. Sin embargo, en todos los casos, México es su referente como país receptor, como lugar de llegada, como espacio de asilo, como un nuevo recinto de sobrevivencia y vida.

Del universo de estudio sólo se emplearon unos cuantos casos para ilustrar parte de los planteamientos formulados en este estudio: ¿De qué manera estas experiencias y su vinculación con los contextos históricos le dio un sentido vivencial a los significados reales y simbólicos de su ser húngaro y su ser judío? ¿Cómo a través de las interpretaciones (percepciones y representaciones) que estos sujetos les confieren a sus identidades y que se encuentran expresadas en una diversidad de significados y pertenencias individuales, comunitarias y nacionales, aparecen a su vez mediadas por los espacios de permanencia y movilización en distintas etapas de sus vidas de manera singular y diferencial? Las entrevistas en profundidad nos permitieron introducirnos en los contextos donde confluían de manera significativa las identidades, las experiencias migratorias, los procesos de incorporación y de integración vistos a la luz de diferentes espacios históricos modernos y contemporáneos, y analizar los significados acerca de la percepción de su identidad judía y el rol o roles con que ésta fue asumida.

Cada sujeto se representa a través de su trayectoria de vida: de una gama de referentes identitarios, experiencias personales y relaciones sociales que se viven en procesos dinámicos de ser en sí y en relación con los otros. Los elementos simbólicos y el bagaje histórico provenientes de su génesis, transmitidos generacionalmente en la historia familiar, los confrontó y conflictuó como individuos y como grupo, sin poder olvidar que, a pesar de que el Estado y la sociedad húngaras pretendieron adscribir su definición y ubicación identitaria, fue su condición judía, la que los definió como común 
denominador. A pesar de sus diferencias, los judíos húngaros compartieron un origen judío y una condición diaspórica que subrayó su complejidad identitaria.

Como plantea Stuart Hall (va. Whitfield, S., 2013): "Las identidades pueden sufrir una transformación constante. Lejos de ser eternamente fijas esencializando el pasado, están sujetas al juego continuo de la historia, la cultura y el poder". De esta confrontación que emerge del sujeto y del contexto, de sus relaciones y sus representaciones, queremos dar cuenta en este artículo.

Tres ejes analíticos básicos nos permiten plantear e identificar aquellos eventos y experiencias que en sus trayectorias temporoespaciales, fueron transformando sus identidades y sus pertenencias, sus relaciones y vínculos familiares, comunitarios y nacionales de manera significativa en el marco de la modernidad:

- Nacionalismo y asimilación como referentes de identificación y pertenencia: Controversias identitarias en un marco de ideologías y religiosidad.

- Respuestas judías a la exclusión promovida por el antisemitismo y el nazismo.

- México, los judíos húngaros inmigrantes y sus referentes identitarios.

\section{Nacionalismo y asimilación como referentes de identificación y pertenencia: Controversias identitarias en un marco de ideologías y religiosidad.}

Hungría llegó a tener la segunda mayor población judía del continente, casi un millón en la víspera de la Primera Guerra Mundial. La diversidad judía, producto de dos olas migratorias tanto del Centro como de Europa Oriental, mantuvo características distintivas, diferentes grados de pertenencia e integración nacional, así como diferentes 
grados de religiosidad, entre la Ortodoxia y el sector $\mathrm{Neólogo}^{2}$, una variante del Conservadurismo que surge en Hungría después de la Emancipación.

En la tercera parte del siglo XIX, una proporción significativa de los judíos húngaros, ya fueran ortodoxos o asimilados a la cultura y a la lengua magyar, se identificaban con el nacionalismo húngaro. Muchos judíos voluntariamente abandonaron la práctica religiosa y aprendieron a hablar magyar como muestra de lealtad al Estado-Nación húngaro y signo de su deseo de llegar a ser ciudadanos plenos. Goldstein (1995) señala que esta asimilación temprana de los judíos húngaros fue a través de la elección del idioma y la promesa de la ciudadanía húngara. En este particular "contrato social” entre la clase liberal gobernante y los judíos en proceso de asimilación, se clasificaba a los judíos como magyares por su nacionalidad, pero se les denominaba "israelitas" (Mars, L. 1999; L., Goldstein1995; Silber, M. 2008). Kovács (2013) puntualiza que “a 120 años de la Emancipación política de los judíos respecto a los límites y la estructura descansaban en un 'contrato de asimilación'”.

Durante el Imperio austrohúngaro, los judíos, insertos dentro del paradigma liberal emancipador, contaron con el apoyo de los políticos nobles húngaros liberales quienes asumieron una posición firme contra el antisemitismo. Dependieron de la buena voluntad del emperador Francisco José I, incluso en contra del alto clero y de la aristocracia, en los que prevalecía el sentimiento antisemita. Casi todos los objetivos judíos parecían alcanzables en esta alianza, a grado tal que al proporcionarles en 1895 la denominación “israelita" aceptándolos como comunidad autónoma —sumándose a las cuatro "denominaciones históricas", junto con el catolicismo, el luteranismo y el calvinismo-, creyeron que ello sería garante de su aceptación (Kóvacs: 2010).

\footnotetext{
${ }^{2}$ Los neólogos son un segmento de la corriente Conservadora judía que se inclinó hacia la integración de los judíos con la sociedad húngara durante la época de la Emancipación, en el siglo XIX. La ruptura con la Ortodoxia se institucionalizó en 1868-1869 con el Congreso Judío Húngaro, y se convirtió de facto en una corriente separada. Los neólogos permanecieron independientes organizacionalmente en los territorios cedidos bajo los términos del Tratado de Trianón en 1920 y aún hoy en día, son el mayor grupo entre los judíos húngaros (Silber, M., 2008).
} 
“Mi mamá vivió y nació bajo el Imperio austrohúngaro y cuando escuchó que los húngaros iban a regresar estaba feliz porque el emperador austriaco, Francisco José les dio muchas libertades a los judíos. Entonces se vivía bastante tranquilo y bien. Desgraciadamente veinte años después, toda la zona de Transilvania sufrió las consecuencias". (Entrevista a Agnes Brawn y Peter Lang, 2009).

Los judíos residentes en Hungría durante el siglo XIX y las primeras décadas del siglo XX contribuyeron a la construcción de la patria húngara y la lengua húngara.

“Éramos tres hermanos que nacimos en Budapest. Los tres estábamos convencidos de ser húngaros cien por ciento, de sangre húngara y dar todo por nuestro país... Cinco de los siete hermanos de mi padre eran hombres y lucharon en la Primera Guerra Mundial por Hungría. Entonces usted puede imaginarse que sí éramos chauvinistas, más que la verdad”. (Entrevista a Max Daniel Halpert, 2010).

Los antepasados de los entrevistados vivieron en Hungría cuando ésta formaba parte del Imperio austrohúngaro (1867-1918). Ellos tuvieron la posibilidad de elegir la nacionalidad húngara y el alemán como idioma preponderante.

“En Bratislava las familias más cultas hablaban alemán. Mi padre, Kalmen Hirshfeld nació en Eslovaquia, que perteneció a Hungría. En aquel entonces era parte del Imperio austrohúngaro y su idioma natal era el alemán. Toda la familia se trasladó de Eslovaquia a Budapest cuando mi papá tenía doce años. Tuvo que aprender húngaro, lo hizo tan bien que sobresalió y fue premiado en su bachillerato. También estudió en el jeder y continuó con estudios ortodoxos. La familia era liberal. A los 27 años mi 
papá empezó un negocio de costales y quebró como veinte veces porque no era comerciante, era intelectual. Mi madre nació en Budapest. Sus padres eran de origen alemán. En Hungría desde hace siglos y durante las dos Guerras Mundiales vivió una minoría alemana muy numerosa, no sólo judía que pertenecían al Imperio austrohúngaro. Mi abuelo materno nació en Eketz (creo que en la parte occidental) y mi abuela nació en Balkapiskistaj (mina de Bestel) en Eslovaquia. Mi abuelo materno fue protestante y mi abuela católica. No olvides que la religión era parte integral e explícita en los documentos (tengo el acta de matrimonio de mis abuelos paternos)"’. (Entrevista a Yoel David, 2010).

“Mi abuelo, el padre de Lazlo Czitrom, nació en Sighisoara, Hungría, en 1878. Era médico y participó como oficial en el ejército austrohúngaro durante la Primera Guerra Mundial. Su madre nació en Pecsej en el condado de Szilagy en Transilvania, Hungría, en 1888. Era una mujer con educación, hablaba húngaro, rumano y francés. Era socialista y sufragista cuando todavía tenía a los hijos todavía en casa”. (Entrevista a S. Czitrom, 2005).

Los judíos ocuparon una posición central en la economía húngara y jugaron un papel clave a la vuelta del siglo veinte, antes de la disolución de la monarquía. El acelerado proceso de asimilación que experimentaron amplios grupos judíos a lo largo del siglo XIX y el relevante papel que jugó la población judía en la fundación del Estado moderno en Hungría, se reflejó en la participación de empresarios, comerciantes, profesionales, artesanos y trabajadores urbanos judíos en la construcción del capitalismo naciente en Hungría. Al iniciar el siglo XX, una cuarta parte de la población de Budapest y la mitad 
de los abogados y los médicos de Hungría eran judíos, a pesar de que el grupo judío únicamente representaba un 5-6\% de la población del país. La inmensa mayoría de la población húngara estaba compuesta por pequeños y medianos propietarios agrícolas, campesinos, terratenientes aristócratas, militares y burócratas, mientras que los judíos estaban sobre representados en los sectores sociales que propiciaban la modernización capitalista (Silber, M., 2010; Szente Varga, 2004).

Esta particularidad histórica en la identidad de los judíos húngaros se presenta en 1867 , en el contexto de la Monarquía Dual ${ }^{3}$, donde se reconoce al Reino de Hungría como entidad autónoma dentro del Imperio austríaco ${ }^{4}$. Los judíos húngaros recibieron en ese mismo año la Emancipación ${ }^{5}$ con el reconocimiento de sus derechos ciudadanos, a cambio de su aceptación de la magyarización cultural ${ }^{6}$. Para los judíos esto significó la adquisición de la lengua húngara, la aceptación de nombres húngaros, y su autorreconocimiento y reconocimiento por los otros como ciudadanos húngaros de religión judía o israelita. Cabe señalar que no fueron considerados como un grupo étnico o nacionalidad como otras minorías nacionales. En 1890, tres cuartas partes de la población judía establecía que el magyar era su lengua materna y en las regiones del noreste declaraban que su idioma era el alemán, en ausencia del idish como opción ${ }^{7}$ (Silber, M. 2008).

\footnotetext{
${ }^{3}$ La Monarquía Dual surgió de un acuerdo tras una serie de derrotas austríacas. El acuerdo fue en la práctica un pacto entre los nacionalistas magyares y la corona, aceptado por conveniencia por los alemanes y, en menor medida, por polacos y croatas. Antes de 1918, Hungría estaba conformada por el territorio que actualmente ocupa, por Eslovaquia y Croacia así como partes de Serbia, Rumania, Ucrania y Austria. Desde el segundo tercio del siglo XIX Hungría fue el escenario de serios conflictos nacionalistas. Además de la población mayoritariamente católica romana había luteranos, calvinistas, unitaristas, católicos griegos y griegos ortodoxos así como judíos. Esta diversidad fue una fuente de tolerancia y de tensión religiosa.

${ }^{4}$ Con la disolución de la Monarquía austrohúngara (1918-19) Hungría tuvo que aceptar su partición en dos Estados y la pérdida territorial de importantes zonas del antiguo Estado. Transilvania fue adjudicada a Rumania, Voivodina, Bosnia y Herzegovina e incluso territorios situados en Eslovenia y Croacia a Yugoslavia, Bucovina a Ucrania y la otra orilla del Danubio, donde había una importante comunidad húngara, a Eslovaquia. (Szente- Varga,2004).

${ }^{5}$ Como plantea S. W. Baron (1983) "hay que recordar que la Emancipación judía constituyó una necesidad histórica tanto para el Estado moderno como para los propios judíos".

${ }^{6}$ Se estableció el magyar como el idioma oficial del reino y el compromiso lingüístico se convirtió en el único prerrequisito para reclamar la ciudadanía. (Goldstein, D. 1985).

${ }^{7}$ Hacia 1880 , el $58.5 \%$ de los judíos dentro de las fronteras húngaras de aquel tiempo declararon al magyar como su lengua materna y para 1910 eran ya 77.8\% (Deak 1983). Este autor calcula que entre la década 
"Mi padre participó en la Primera Guerra Mundial. A comienzos de la guerra su ciudad fue rodeada por los rusos sin municiones ni comida y tuvieron que rendirse. Estuvo cinco o seis años en la cárcel como prisionero de guerra. A los 27 años, en 1914, fue voluntario, quienes tenían bachillerato tenían que estar un año en el servicio militar húngaro. Mi padre estuvo primero en Siberia, después en Vladivostok más cerca del Japón y en esa época fue la revolución, los rusos blancos y todo el relajo. Regresó a Hungría en 1920-21, después de muchos años de estar en prisión, aprendió un poco ruso, alemán era su idioma natal, húngaro, latín que había aprendido en el colegio y también griego”. (Entrevista a Joel David, 2010).

En 1910, el 7-8\% la población judía se dedicaba a las profesiones libres y el 70\% de la población se ubicaba en la industria y el comercio, ocupando todos los espacios de la economía nacional. La sociedad veía una sobresaturación económica y cultural de los judíos y ello hizo que floreciera un franco antisemitismo, como resultado de los conflictos en la era post el acuerdo de Trianón (Silber, M. 2008).

"Nos sentíamos muy húngaros, éramos chauvinistas. Mi educación, mi formación era húngara. Por mi país podía hacer todo. Después de la Primera Guerra Mundial me dolió mucho la decisión del Trianón, cuando le quitaron a Hungría parte del territorio. Nos separaron totalmente, yo

iniciada en 1780 y el año 1914, más de 700 mil judíos se convirtieron en magyares y en consecuencia en ciudadanos por el sólo hecho de su elección de idioma. Otra particularidad importante es la concepción de alteridad respecto a los judíos de la historia húngara es que los que llegaron a Budapest en el siglo XIX no fueron identificados como un grupo étnico separado sino que fueron registrados como alemanes (Deak 1983 citado en Goldstein, 1985). 
era húngaro de una familia de religión judia”. (Entrevista a Max Daniel Halpert, 2010).

El indicador de la progresiva asimilación fue el número creciente de matrimonios mixtos después de 1895. Esta rápida asimilación se acompañó de una creciente movilidad social. En 1910, más del 40\% de los médicos y abogados del país eran judíos. En comparación con otras comunidades judías, la mayoría de los judíos no se enfrentaban a la pobreza tal como la vivían en Rusia, Ucrania, Polonia o suelo rumano. (Kovács, A. 1997).

"Los padres y los abuelos de mi padre eran judios muy tradicionales y llevaban a cabo todas las ceremonias. Cuando mi padre se fue a estudiar a Brno (Checoslovaquia), ciudad cosmopolita, entró en contacto con grupos de izquierda, con los marxistas, con los comunistas. Empezó a ver la vida de manera distinta y cuando regresó para ver a sus padres les anunció que ya no era judio”. (Entrevista a S. Czitrom, 2005). “Aunque había rabinos en su árbol genealógico su familia no era muy religiosa, Lazlo había renunciado a su fe judía, sin embargo, se unió a la asociación estudiantil judía en Brno y también apoyó al Partido Comunista, por lo que fue expulsado de la Escuela Superior y también de Checoslovaquia”. (va. Staropolsky, M., 2013).

Después de la Primera Guerra Mundial, los judíos no fueron vistos como parte integral del desarrollo de Hungría, sino de manera utilitarista. La asimilación fue sólo superficial, fue un disfraz que empleó la sociedad húngara para enmascarar el reconocimiento a los judíos; no representó su inclusión verdadera como ciudadanos de manera integral. Les exigieron perder su identidad judía y su singularidad, cultural y socialmente debían magyarizarse pero, al mismo tiempo, se les denominó “israelitas”, obligándolos a vivir 
una permanente disyuntiva. Como señala E. Mendelsohn (1983), "el antisemitismo no era sólo para los inmigrantes que portaban caftanes y se resistían a la asimilación, sino contra los ciudadanos de clase media 'cosmopolitas' judíos que 'aparentemente' se habían asimilado y habían encontrado su lugar en la sociedad".

También desde la religiosidad los judíos húngaros presentaban una diversidad de posturas; en general, los neólogos prevalecieron sobre la ortodoxia promoviendo la secularización de los judíos y su integración a la sociedad. Otro de los referentes como forma de identificación fue el idioma, paulatinamente el húngaro fue lenguaje cotidiano y en la educación. Se convirtió en el idioma de enseñanza en las escuelas públicas donde se enseñaban las diferentes denominaciones religiosas para cada sector, y a las que asistían también la mayoría de los judíos.

"Nací en 1921, fui a una escuela en Budapest (1926), era una escuela de gobierno donde teníamos dos horas de religión a la semana. Los judíos teníamos clases de judaísmo y no creo que eso se hiciera en otros países”. (Entrevista a Clara Forgacz, 2009).

"Nací en Kosice, hoy Eslovaquia, en 1921. En general, los judíos hablaban húngaro y en mi casa sólo eso hablábamos. Iba a una escuela pública, nada más había unas cuantas escuelas de las diferentes religiones. Esa escuela tenía el idioma húngaro, mi papá me dijo que había que aprender el idioma de la nación en donde uno vive. En la escuela aprendí también el eslovaco y el checo, ya que los maestros eran de la República checa. Mis abuelos hablaban alemán, ellos vinieron de Tatra, una cadena de montañas. Aunque no se hablaba el idish, mi abuelo paterno era el Rosh Akol (presidente) de la comunidad ortodoxa. Tenía él 
una biblioteca de literatura hebrea, no solamente libros de rezo". (Entrevista a Eva Goldstein, 2010).

Ser húngaro significó para muchos de los judíos declarar una postura nacionalista incondicional, con plena conciencia de las implicaciones entre su deseo de ser húngaro y su voluntad de dejar de ser judío, entre las políticas incluyentes de permitirlo con reservas y limitantes, y las políticas excluyentes con un fuerte tinte antisemita que promovieron no serlo, a la luz de las sucesivas transformaciones geopolíticas que sufrió Hungría.

Cabe señalar que el Movimiento Nacional Judío, que emerge en esa época ofreciendo una moderna identidad secular, tuvo escasa resonancia en Hungría. Ahí, en el hogar de Teodoro Herzl, el máximo exponente y defensor del sionismo, los judíos húngaros intentaban una genuina asimilación a fin de integrarse a la sociedad y el sionismo les representaba una forma de infelidad al nacionalismo húngaro. Sin embargo, posteriormente hubo quienes lo adoptaron participando en movimientos juveniles (tnuot), haciendo aliá (emigrando)a Israel y brindando apoyos al naciente Estado de Israel $^{8}$ (Kóvacs, 2010).

"De Mád nos mudamos a otra ciudad Klshkunfirethasen, donde hice mis estudios primarios en una escuela ortodoxa. Tenía esta ciudad poco más de mil judios entre ortodoxos, neólogos, jasidim, ultra-jasidim y ultraultra jasidim. Yo sigo siendo ortodoxo, me pongo tefilin (filacterias) todos los días, celebramos las fiestas y soy muy sionista, aunque en Hungría ser

\footnotetext{
${ }^{8}$ Para Jacob Katz, la historia judía moderna húngara fue un proceso único de asimilación social y cultural que llegó a ser sustancialmente determinante en el destino de la judería húngara tanto en los buenos como en los malos tiempos (Jacob Katz, 1977, 45-53.) La idea de ser judío podría significar una alternativa nacional de pertenencia que provocaba una serie de reacciones indignantes como la publicada en el órgano más importante de la judería húngara contemporánea" No hay un sionismo húngaro, no hubo y nunca lo habrá. Esto no es para reconciliarse con el alma húngara. Un húngaro es un húngaro a pesar de ser judío, su alma es húngara, sus sentimientos son húngaros... El sionismo húngaro sólo puede tener una sola designación: alta traición" Lo que Teodoro Herzl sintió y que Jacobo Katz históricamente diagnosticó es probablemente verdad (Baron,S., 1983; Kovács, 2010).
} 
sionista era sinónimo de comunista. Soy muy judío, no tanto como religioso, sino como sionista”. (Entrevista a Luis Stillman, 2009).

Al momento de migrar a México, ¿fueron estas categorías identitarias incluyentes o excluyentes, complementarias o contradictorias? ¿Implican ambigüedad, dualidad, integración o definitiva negación? ¿Ser judío o no serlo?, ¿ser húngaro o no serlo?, ¿ser judío y húngaro? ¿ser húngaro y no judío, aunque tenga ancestros judíos? ¿Fue una condición que va más allá de la etnicidad y del nacionalismo en el abanico donde lo cultural, la religión y la religiosidad, lo ideológico, entre otras, se muestran como posturas etnocentristas, universalistas o cosmopolitas?

El eje permanente del antisemitismo, y luego el nazismo, permeó las decisiones. La magyarización pasó de una socialización, aculturación lingüística y asimilación, a mostrar su verdadero rostro: la exclusión y las contradicciones que obligaron a muchos judíos a migrar, a retornar al origen étnico y recuperar su identidad judía. Entre la gran diversidad de historias de los inmigrantes, ${ }^{9}$ hay quienes se consideraban primordialmente pertenecientes a la nación húngara y priorizaban la identidad nacional, y otros que subrayaban la religiosidad y la pertenencia comunitaria como un referente sustantivo y, por ende, se sintieron excluidos de la sociedad húngara en general. Hay también casos controvertidos que muestran ambas tendencias y son claves para comprender la gama de posibilidades que plantean estas identificaciones representadas en sus identidades y pertenencias. Por lo tanto, nos encontramos con un grupo sui generis que nos muestra cómo las diversidades de sus visiones de vida reflejan las particularidades de posturas nacionales, ideológicas, políticas, religiosas y grados de religiosidad, un marco de gran riqueza y complejidad analítica.

\section{Respuestas judías a la exclusión provocadas por el antisemitismo y su continuidad con el nazismo.}

\footnotetext{
${ }^{9}$ Nuestro universo de estudio se centró en personas que fueran de origen judío húngaro que habían inmigrado a México independientemente de su edad, de las circunstancias y del momento de la inmigración. Entre quienes fueron identificados como descendientes de judíos húngaros generalmente se consideraron a los hijos o nietos, en un momento en que los padres ya habían fallecido.
} 
Los argumentos antisemitas se fueron incrementando desde las primeras décadas del siglo XX y después de la Primera Guerra Mundial. Los judíos húngaros fueron acusados de sabotear el servicio militar, de cobardía, de mercado negro y fraude de los envíos militares y continuaron públicamente las polémicas sobre la "cuestión judía" (Silber, M.,2008).

"Los judios fuimos vistos como extranjeros: judios (zsidok) y no como húngaros de religión judía (izraelitak)”. (Entrevista a Violeta Stern de Klein, 2008).

Con el declive del Estado húngaro se mostró un fuerte antisemitismo a raíz de las consecuencias de la guerra, el desmembramiento de Hungría que acompañó a la reducción territorial que dejó el tratado del Trianón ${ }^{10}$, así como las dos fracasadas experiencias en las que un pequeño grupo de activistas radicales, la mayor parte de ellos judíos convertidos, jugaron un papel desproporcionado en la burguesía, pero especialmente en las revoluciones comunistas de 1918 y 1919. Se reasignaron nuevos alineamientos entre los estados y sus identificaciones nacionales. Mientras muchos judíos retenían su lealtad nacional con Hungría, en Alemania, Austria, Checoslovaquia, Rumania y Yugoslavia otros asumían nuevas identidades incluyendo las identidades nacionales judías.

"Provenientes de Hungría y de los países aledaños que formaron parte del

Imperio austrohúngaro y que luego se desmembraron y se configuraron en

\footnotetext{
${ }^{10}$ El Tratado de Trianon, 4 de junio de 1920 fue rechazado por todo el pueblo húngaro. El reino de Hungría pasó de 325 mil 411 kilómetros cuadrados en 1914 a tener 92 mil 963; de los 20.9 millones de habitantes, ahora quedaban 7.6 millones. Por el sur perdía el $6.44 \%$ del territorio y un millón y medio de ciudadanos; por el este, el $31.59 \%$ y más de cinco millones y cuarto de habitantes y por el norte el resto del territorio fue recortado y perdió más de tres millones y medio de habitantes. Quedaban fuera de territorio húngaro más de tres millones de magyares, de ellos, unos setecientos mil en Rumanía, medio millón en Yugoslavia y otro en Checoslovaquia. En toda Hungría se consideró este acuerdo como una imposición y desde un primer momento surgieron anhelos revisionistas. La guerra, el periodo soviético y los 350 mil refugiados incidieron en la problemática de la cohesión social. Las minorías nacionales representaban apenas un 10\% de la población: más de medio millón de germanos y 150 mil eslovacos. Los judíos eran 473 mil (Pérez, C., 1994).
} 
otros Estados, nosotros seguimos hablando y pensando como húngaros".

(Entrevista a Agnes Brawn y Peter Lang, 2010).

La proclamación de la República de Hungría ${ }^{11}$ en 1918, en la que participaron algunos miembros de la burguesía judía, se enfrentó a las movilizaciones masivas del movimiento obrero, e inmediatamente después, a movimientos de masas que mezclaron reinvindicaciones de carácter social con la denuncia de violaciones de los derechos nacionales en el seno de Hungría. Croatas, serbios y eslovacos también buscaban reivindicar su autonomía política e igualdad lingüística frente al predominio húngaro. (Moreno Mínguez, 2015). Como consecuencia del Terror Blanco, como se llamó a esa efímera República de Hungría, un grupo de comunistas comandados por Bela Kun, quien era judío, junto con los socialdemócratas de izquierda y socialistas revolucionarios, fundaron el Partido Comunista de Hungría, en 1919, que llega al poder. Este intento bolchevique falló a finales de julio de ese año debido a las dificultades económicas internas, a la alta participación de intelectuales y empleados estatales en el mercado laboral y a la intervención extranjera, y después de un breve periodo de tiempo, el ejército nacional, compuesto por radicales y adherentes del viejo sistema y guiados por el almirante Miklós Horthy, tomó el poder en 1920 (Silber, 2010).

"Miklos Horthy que fue después el regente, el hombre fuerte de la posguerra, era un antisemita tradicional que daba crédito a los "Protocolos de los Sabios de Sión", pero en lo que respecta al problema judío él había sido un antisemita toda su vida. Consideraba intolerable que en Hungría todas las fábricas, bancos, grandes fortunas, negocios, teatros, periódicos, grandes comercios, etcétera, tuviesen que estar en

\footnotetext{
${ }^{11}$ Hungría vivió, ante la disolución de la monarquía dual, dos fracasadas experiencias: la de los burgueses radicales y la de los sociales demócratas, muchos de los cuales eran judíos o intelectuales nacidos como judíos. Ganaron un importante rol en la revolución burguesa lidereada por Mihály Karolyi. La proporción de los judíos o los de origen judío que habían servido como ministros en el gobierno de Károlyi, en la República Soviética Húngara no tenía precedentes. De los 29 miembros del Consejo de Gobierno Revolucionario, 19 eran judíos (Silber, 2010).
} 
manos de judíos y que estos fuesen la imagen que ofrecía Hungría, sobre todo en el extranjero”. (Entrevista a Max Daniel Halpert, 2010).

Aunque sólo una pequeña fracción de los judíos de Hungría participó en las revoluciones, la mayoría, que era de clase media ${ }^{12}$, se opuso a la comuna desde sus primeros días y algunos inclusive apoyaron activamente las actividades contrarrevolucionarias. Esto provocó que se fortalecieran los sentimientos antisemitas en Hungría, debido principalmente a la alta participación de judíos en el impopular golpe de estado y revolución bolchevique ${ }^{13}$. Este rechazo se manifestó inclusive en disposiciones gubernamentales en su contra. La primera de las cuales apareció en 1920 y desde finales de los años treinta fue seguida por varias leyes que perjudicaron abiertamente a los judíos definiéndoseles desde 1939 ya no solo con base en la religión, sino más ampliamente, dentro de un sentido étnico ${ }^{14}$ (Silber, 2010, Szente Varga, 2008).

"Después de la guerra hubo un tiempo bajo el comunismo, que fue horroroso, después vino el Terror Blanco. Mi papá siempre fue de izquierda, pero no pertenecía a ningún partido. Era comunista de alma, es decir, él quería la igualdad para todos. En ese tiempo en Tocai, región

\footnotetext{
${ }^{12}$ La mitad de los dirigentes comunistas eran de origen judío y representaban el $6.2 \%$ de la población. Predominaban en ciertos sectores y constituían la mitad de los abogados, $60 \%$ de los médicos, $53 \%$ de los comerciantes independientes, $80 \%$ de los financieros y banqueros, en la industria eran 39\%, en las finanzas $44 \%$ y en el comercio $48 \%$. Además, abundaban los periodistas y los artistas. Los judíos fueron culpados de todos los males, y así, los liberales y comunistas fueron acusados de estar manipulados por ellos.

${ }^{13}$ Las atrocidades anticomunistas y anti-judías en la región central del país y en las ciudades y pueblos de Transdanubia acompañaron al establecimiento del régimen en agosto de 1919. Los actos antisemitas fueron realizados como retribución por el "terror rojo" que, en realidad tuvo más víctimas judías que no judías (se estimó que el número de judíos en alrededor de 3 mil). (Silber, 2010).

${ }^{14}$ Hay varias razones para este "nuevo" antisemitismo: la búsqueda de un chivo expiatorio culpable de la derrota en la Primera Guerra Mundial; las dificultades experimentadas por los refugiados húngaros en los gobiernos sucesores planteó sentimientos negativos; la competencia económica; la prominencia de los judíos en la vida económica y cultural; y el papel de algunos judíos, o de aquellos que fueron percibidos como tales en las revoluciones. El ingrediente más importante del sentimiento anti-judío fue la manera en que Hungría se estableció de nuevo después de la pérdida de los territorios nacionales y la integración nacional se basó en principios étnicos. Después de la estabilización de la situación política en 1921 los actos violentos antisemitas disminuyeron pero la sociedad húngara continuó caracterizándose por ser nacionalista del ala derecha y por sus actitudes antijudías.
} 
vinícola, todos se llevaban bien: los judíos, los sacerdotes: el católico y el protestante. Era un pueblo muy tranquilo. Sin embargo, con el terror comunista primero buscaron a los potentados del pueblo, los Zimmerman y los Weissman (que se fueron a México), y le entregaron las llaves a mi abuelo paterno y éste a mi padre. Cuando vino el Terror Blanco, dijeron que mi papá era un comunista y lo vinieron a buscar los gendarmes que traían un gorro con plumas de ganso en los cascos y eran famosos por terribles. Afortunadamente logró huir". (Entrevista a Clara Forgacz, 2009).

Horthy trajo consigo la pacificación (después de la Revolución Bolchevique y del Terror Rojo y del Blanco) y la consolidación política del país que duró más de dos décadas, pero sin implicar una vida democrática. (Szente Varga, 2008.) Sin embargo, promovido por los radicales de derecha y los fascistas, se retomó el sentimiento antisemita y la necesidad de definir "la cuestión judía".

"Vivimos una vida europea, podríamos decir, en Hungría. Los judíos estaban metidos en todos los aspectos, en todas las ramas hasta que nos llegó la mera hora de las restricciones. Vivíamos muy bien, vivíamos casi libremente, podíamos viajar al extranjero antes de eso, los que tenían dinero inclusive muchos se fueron". (Entrevista a Max Daniel Halpert, 2010).

Durante el régimen de Horthy las políticas se mantuvieron abiertamente antisemitas, reprimiendo a los judíos húngaros lo más posible. Uno de los medios por los que alcanzó esto fue limitando a los judíos a la educación superior. En 1920, bajo la influencia de movimientos estudiantiles antisemitas y de círculos conservadores cristianos, la Asamblea Nacional aprobó la primera ley judía en la Europa post Primera Guerra 
Mundial, la así llamada ley Numerus clausus (Art. 25 XXV 1920). Aunque no estaban mencionados explícitamente, esta ley empleaba categorías de nacionalidad y raza dirigidas principalmente a los judíos, que hasta entonces nunca habían definidos legalmente en dichos términos. El numerus clausus delimitó a un 6\%, correspondiente al porcentaje de judíos en la población general, del porcentaje de estudiantes judíos permitidos en los institutos de educación superior. Esta ley, que de manera reservada concebía a los judíos húngaros como una minoría racial nacional y propició la asimilación, sobre todo en aquellos judíos que habían proclamado su lealtad a la nación húngara, forzó a muchos de ellos a emigrar o a tomar trabajos menores.

“A los 18 años de Transilvania Lazlo se va a Checoslovaquia. En 1929 inicia sus estudios de Arquitectura en la Escuela Técnica Superior Alemana de Brno, Checoslovaquia, que aceptaba alumnos judios provenientes de Europa del Este que no podian seguir estudios universitarios en su propio país, por los restrictivos numerus clausus impuestos por las leyes antisemitas. Checoslovaquia era una república democrática al estilo occidental, sin leyes de discriminación racial y con un partido comunista legal. Aunque había rabinos en su árbol genealógico, su familia no era muy religiosa. Lazlo renunció a la fe judía por considerarla incompatible con sus convicciones políticas liberales. Sus padres no eran muy religiosos, aunque hubo rabinos en la generación de sus bisabuelos maternos y su abuelo paterno que lo habían sido. Sin embargo, se unió a la asociación estudiantil judía en Brno, también apoyó al Partido Comunista y debido a sus actividades políticas fue expulsado de la Escuela Superior y también de Checoslovaquia”. (Entrevista S. Czitrom, 2005; va. Staropolsky M., 2013). 
Este proceso de selección institucionalizado continuó con las leyes antijudías en la década de 1930 y restringió en diversos grados las posibilidades de empleo de los judíos en ciertas profesiones y su acceso a la educación universitaria.

"Lazlo pudo continuar sus estudios en la Reale Scuola Superiore di Architettura en Florencia donde obtuvo el título de Dottore in Architettura, en 1934. Hizo el servicio militar en Rumania y fue rechazado como oficial por ser de origen húngaro". (va. Staropolsky, M., 2013).

"Una vez que terminé la secundaria tuve que cooperar con el mantenimiento de la familia. Esto lo hice con mucho gusto, alegría, convivencia familiar. No pude continuar estudiando por dos motivos: económicos y por el numerus clausus para los judios por lo que mis padres me buscaron un oficio”. (Entrevista a Max Daniel Halpert, 2010).

Cabe destacar, entre las respuestas judías a esta situación, la tibia reacción de los representantes de la comunidad judía húngara, quienes bloquearon la posibilidad de buscar apoyo en la Liga de las Naciones debido a las presiones del gobierno. Asimismo, frenaron las iniciativas que proponían otras organizaciones internacionales judías.

En la segunda mitad de la década de 1920 y la primera mitad de la de 1930, la elite política voluntariamente estuvo de acuerdo en que "la cuestión judía tenía que ser resuelta", pero intentó moderar las demandas antisemitas del ala derecha por considerar el rol económico de los judíos, las reacciones del exterior, las dificultades en llevar a cabo medidas restrictivas y el problema de los estados sucesores ${ }^{15}$. A pesar de las protestas de las organizaciones húngaras judías, la ley Numerus clausus continuó por muchos años, aunque en algunos casos (especialmente en las universidades rurales) su implementación

\footnotetext{
${ }^{15}$ Los estados sucesores fueron los nuevos estados creados a partir de la Primera Guerra Mundial cuando Hungría se conformó como un país nuevo a raíz de la desmembración de sus territorios.
}

Cuadernos Judaicos - ISSN: 0718-8749 
fue limitada. Después de largas negociaciones, la ley fue modificada en 1928, pero no totalmente eliminada.

“Nací en 1921, hice la primaria en la escuela de la comunidad, luego pasé al gimnasium San Ladislao, que era muy católico, y aunque había antisemitismo, no era tanto. Después de ocho años, dos de los cinco judíos que había, uno de ellos fui yo, terminamos con Summa Cum Laude. Ningún católico. Yo quería ser médico, pero me rechazaron e insistí. Había un resquicio en la ley del numerus nulus para entrar en la Facultad de Leyes. Me planté en la oficina del rector de la Universidad de Szeged, la segunda ciudad de Hungría, él había sido premio Nobel en 1936 por aislar la vitamina $C$ del pimiento, e hice un gran escándalo cuando la secretaria me quiso sacar. Salió el rector y no sólo me metió en la Facultad de Leyes sino también me dio una beca. Esto me salvó la vida en 1942 cuando fue el reclutamiento. Los universitarios estaban exentos y no me enrolaron. Mis compañeros estaban en el frente en Rusia y a los otros judios los tenían en labores de trabajo forzado cavando trincheras, cargando municiones con un trato terrible. Miles de jóvenes murieron y yo me salvé”. (Entrevista a Luis Stillman, 2009).

En ese contexto de continuas posturas ambivalentes por parte del gobierno con respecto a los judíos, en 1928 fueron reconocidos como grupo religioso y obtuvieron representación por primera vez en la Cámara Alta del Parlamento. En Hungría, el 65\% eran neólogos y el 29\% eran ortodoxos. La mayoría de las grandes comunidades judías ortodoxas fueron anexadas a los estados sucesores después de la Primera Guerra Mundial y el 5\% continuaron con su status quo antes de la guerra (Silber, 2010). 
Por su parte, desde 1927 se le permitió a la Alianza Sionista renovar sus actividades. A mediados de la década de 1930, el movimiento sionista tenía alrededor de cinco mil miembros y este número llegó a incrementarse a cerca de doce mil. Además, atrajo la atención de sionistas y no sionistas, que coadyuvaron filantrópicamente al Yishuv en Palestina.

Aun cuando Hungría continuó teniendo gobiernos de derecha, la situación de los judíos se mantuvo estable. Sin embargo, después de mediados de la década de 1930, ante la incertidumbre económica que sufría una amplia gama de personas de clase media, incluidos funcionarios públicos y militares, se reavivó el antisemitismo. A este despertar se sumaron grupos radicales de extrema derecha, como fue el movimiento Cruz Flechada, que aprovecharon la animadversión social y buscó retomar el carácter revisionista del gobierno, apelando al apoyo de la Alemania nazi ${ }^{16}$.

El borrador de la primera ley judía de Hungría, presentada el 8 de abril de 1938, limitaba a un $20 \%$ la proporción de judíos en las profesiones liberales, en trabajos administrativos y como empleados de empresas comerciales e industriales. Judío ahora se definió para incluir a aquellos que se habían convertido después de 1919 o habían nacido de padres judíos después de este tiempo. Aunque los partidos de oposición la atacaron fuertemente, este proyecto fue ratificado por ambas cámaras del Parlamento (Ley XV de 1938). La segunda ley judía (Ley IV de 1939) se anunció el 5 de mayo 1939; esta legislación amplió la definición de judío sobre una base racial y además limitaba las actividades económicas de los considerados judíos. La proporción de $20 \%$ establecido por la primera ley judía, se redujo al $6 \%$.

“En 1940 y 1941, los judíos sólo podían ocupar el 6\% de los trabajos y despidieron a mi padre que trabajaba en el área del petróleo. De un día a otras muchas personas, inclusive unos muy preparados, se quedaron sin pan”. (Entrevista a Joel David, 2010).

\footnotetext{
${ }^{16}$ Cabe distinguir dos grupos que fueron imitaciones de los nacionalsocialistas alemanes y quienes constituyeron un ejemplo de nacionalismo revolucionario: Cruz Flechada, más tarde el Movimiento Hungarista. También la minoría germana gozó de su partido nazi: el MEM.
} 
Las organizaciones judías, especialmente la Comunidad Israelita de Pest, incrementaron las actividades sociales para ayudar a los judíos que habían sido expulsados de la vida económica. Los afectados por la ley trataron de encontrar la manera de burlarla. El número de conversiones aumentó, unos cinco mil judíos se convirtieron después de la aprobación de la primera ley judía; el número de empleados "cristianos" comenzó a crecer en las empresas "judías"; y algunas personas intentaron esquivar la ley mediante la firma de contratos ficticios que "arianizaban" sus empresas (Silber, 2010).

Las decisiones de Viena, firmadas en 1938 y en 1940, aumentaron la superficie de Hungría. En consecuencia, mientras que en 1930 se habían registrado 444 mil 567 judíos que vivían dentro de las fronteras de post-Trianón en Hungría, el censo realizado el 31 de enero 1941 mostró que, en la población total de 14 millones 683 mil 323, 725 mil eran judíos y de ellos, 184 mil 453 vivían en Budapest. Después de que Yugoslavia se disolvió en 1941, unos 20 mil judíos adicionales quedaron bajo la jurisdicción húngara (Silber, 2010).

La tercera ley judía racista (Ley XV de 1941) prohibía las relaciones sexuales entre los judíos y los cristianos y clasificaban a otras 58 mil 320 personas que no profesaban el judaísmo. En realidad, el número de cristianos de origen judío era mucho mayor que este número, a mediados de 1941 pudo haber excedido a 85 mil.

"Nací en 1920 en Budapest. Estudié en el Colegio Israelita Budapest donde aprendí lo básico de hebreo, pero no para hablarlo. En mi casa hablaban sólo húngaro. Mi familia era liberal, no participaban comunitariamente hablando y sólo respetaban Yom Kipur. En mi casa la religión no era muy importante, había más nacionalismo que judaísmo, aunque yo estudiaba hebreo en la escuela. Mis padres iban al templo únicamente en las fiestas mayores. Mi padre era originario de Transilvania y mi madre de Checoslovaquia que era parte del Imperio austrohúngaro; él era comerciante, se dedicaba a la venta y refacciones 
de bicicletas y participó en la Primera Guerra Mundial. Hablaba alemán e insistió para que yo lo aprendiera, además de tomar clases de latín y francés en la escuela. Cuando entran las tropas alemanas a Hungría en 1939, las condiciones de los judios fueron empeorando (Entrevista a Agnes Brawn y Peter Lang, 2010 ; va. Zaga, M.S; Cohen, C.E., 2002).

En 1940-1941, los judíos fueron excluidos del servicio militar regular y estaban obligados a realizar el "servicio de trabajos forzados". En noviembre de 1942, el trabajo forzado se convirtió en obligatorio para todos los varones judíos entre las edades de 24 y 33 años. Después del ataque de la Unión Soviética, las unidades de trabajo forzado también fueron enviados al frente, donde su número creció gradualmente a 50 mil. Tras el gran avance del Ejército Rojo por el río Don (en enero de 1943), más de 40 mil trabajadores forzados habían muerto o caído en cautiverio ruso.

"Nací un 19 de septiembre de 1924 en Budapest. La escuela empezaba el $1^{o}$ de septiembre en Hungría, me hicieron un examen especial de niño, cuando tenía seis años, para saber si era capaz o no y, como consecuencia, gané un año de la escuela. A los 14 años terminé la secundaria y comencé a trabajar y a estudiar en la escuela industrial durante tres años. A los 17, cuando terminé, ya era un hombre; pude trabajar hasta los 19, cuando me citaron y me llevaron a trabajos forzados hasta los veinte. Estuve en Hungría hasta los 23. Provengo de varias generaciones de húngaros, pertenecía a una familia de clase media. Del lado de mi abuelo materno venían de un pueblo que se llama Munkacs. Era comerciante, tenía abarrotes y ya en la capital siguió en ese mismo ramo en el barrio judío. Mi padre era de un pueblo llamado 
Paradfurdo, pronunciado Perechufardo”. (Entrevista a Max Daniel Halpert, 2010).

“En 1940-41, mi padre tenía cincuenta años, estaba viejo, pero aún así lo llevaron a trabajos forzados. Los húngaros se llevaron a mi hermano, cinco años mayor que yo, como soldado. A los judíos los ubicaban en unidades auxiliares, por ejemplo, para estar en los lugares donde los rusos ponían minas, así que no les importaba si moría un judio" ${ }^{17}$. (Entrevista a Joel David, 2010).

“A los judios se los llevaron ya en 1940-1941. Hungría no había entrado en la guerra, era sólo un aliado pasivo de Alemania. Mi padre tenía 56 años y como a muchos otros judíos se lo llevaron a los Cárpatos, Rusia, a 500 kilómetros de Budapest, para hacer fortificaciones. Mi papá ya había estado en la Primera Guerra Mundial como subcomandante, así que él era oficial, de más bajo rango, pero podía tener uniforme, pero, al fin y al cabo, era jese judío! que supervisaba el trabajo de los demás”. (Entrevista a Joel David, 2010).

"A mi hermano, dos años mayor que yo, mismo mes, mismo día, se lo llevaron dos años antes que, a mí, para el servicio "militar", pero era de

\footnotetext{
${ }^{17}$ Los judíos húngaros sufrieron sus primeras pérdidas en julio de 1941, cuando cerca de18 mil judíos de cuestionable ciudadanía fueron deportados a Ucrania, entonces bajo dominio alemán. La mayoría fueron asesinados cerca de Kamianets-Podilskyi. La segunda gran derrota fue en enero de 1942, cuando los gendarmes y soldados húngaros asesinaron alrededor de 800 judíos en Bácska al mismo tiempo que perseguían partisanos serbios.
}

Cuadernos Judaicos - ISSN: 0718-8749 
trabajos forzados. Mi papá era de la guardia civil en Budapest. Cuando venían a bombardear tenía que hacer su trabajo. Desde niños nos daban uniformes húngaros y hacíamos un servicio militarizado, no militar, en el que nos inculcaron la historia de Hungría. Un joven en Budapest en aquella época era un hombre maduro. Inclusive participamos activamente en el partido social demócrata, que era muy perseguido por el régimen de entonces. Era el único partido que me convencía y además me aceptó por ser judío. Me permitió votar, formar parte de todo lo que es Hungría, ser húngaro". (Entrevista a Max David Halpert, 2010).

La situación de las unidades de trabajo forzado en Hungría mejoró un poco después de 1942, cuando hubo un gobierno más moderado. Sin embargo, en julio de 1942, el parlamento delimitó nuevamente la condición judía. En septiembre lanzó una orden para confiscar las tierras y propiedades de los judíos. A principios de 1943, el gobierno inició un programa para eliminar a todos los judíos de la vida pública y cultural; sólo el 6\% (el porcentaje familiar de judíos en la población general) podía participar en actividades económicas. Las tierras de propiedad o alquiladas por judíos fueron confiscadas casi en su totalidad y la legislación de protección racial separó a los judíos del resto de la sociedad húngara. A principios de 1944, a medida que la situación económica se agravó, Hungría comenzó a buscar a los aliados y, como consecuencia de este acercamiento, Hitler ordenó la ocupación militar de Hungría. El Holocausto húngaro, la destrucción de la mayor parte de la población de los judíos húngaros, hasta ese momento intacta, fue la consecuencia de la invasión del 19 de marzo. Su comienzo fue simbolizado por la aparición del Comando Eichmann en Budapest, entre el 19 y el 21 de marzo.

Desde mayo del mismo año se inició la concentración de judíos en guetos y el día 15 salió el primer tren hacia Auschwitz. En mes y medio se iniciaron las deportaciones de los judíos, sin embargo Horthy las frenó a finales de junio, posiblemente debido a las protestas internacionales e internas, y teniendo en cuenta los éxitos de los aliados. De esta manera, se salvó la vida de los judíos que vivían en Budapest, pero a consecuencia de 
esta medida, Horthy perdió el poder y el nuevo gobierno, de corte político pro-nazi, volvió a las deportaciones.

"Horthy reconocía que odiaba mucho más a los de la Cruz Flechada que a los judios, porque decía que a los judíos se les necesitaba. A pesar de que era antisemita reconoció que los judios éramos útiles, además sabía que la gran mayoría de los judios éramos húngaros, como yo, es la mera verdad". (Entrevista a Max Daniel Halpert, 2010).

El gobierno obligó a los judíos en ese año llevar una estrella amarilla y los excluyeron legalmente de toda actividad pública y laboral. Posteriormente se llevó a cabo la "concentración" de judíos en guetos en el resto de Hungría con excepción de Budapest. Las deportaciones comenzaron el 15 de mayo y después fueron conducidos a los campos de muerte del nazismo. En menos de un año, dos tercios de la comunidad judía húngara desapareció, más de medio millón. (Goldstein, 1993/ Mars,1999).

“En 1944, los judíos hacían colas sin fin, triples colas, kilómetros para conseguir un pasaporte de cualquier país. Las decenas, centenas que escaparon de los campos y contaron de Birkenau y de Maidanek, y les platicaban a los miembros de la comunidad judía de Budapest que a los judios los estaban haciendo jabón. La gran mayoría no les creyó, no quisieron ver esta realidad. ¿Cómo era posible que el pueblo de Goethe, Schiller, Beethoven, hiciera esas cosas?”. (Entrevista Joel David, 2010).

"Mi mamá iba de un sitio a otro buscando a mi padre y a nosotros, que estábamos en la cárcel de la Gestapo. Yo tenía 16 años. Mi mamá nos buscó en los campos de trabajos forzados y nos rescató con documentos 
falsos. Le dio dinero a un guardia que nos permitió regresar, nos llevó a Budapest, pasar de Buda a Pest, y nos metió al gueto principios de noviembre o diciembre de 1944. Cuando los rusos rodearon el gueto de Budapest no hicieron nada, los alemanes habían puesto minas, a nadie le importaba que murieran esos despreciables judíos. El gueto estaba entre dos calles paralelas. Los SS se fueron corriendo y no pulsaron el botón, quizá para evitar que los rusos los pudieran llevar como prisioneros de guerra. Mi madre fue una heroína y a propósito ella, como aitgará (conversa), la llamaron Ruth Elizabeth Katcz David". (Entrevista Joel David, 2010).

El comportamiento de la inmensa mayoría de la población húngara se caracterizó por la indiferencia; hubo modestas protestas de solidaridad y los intentos de rescate fueron la excepción (sobre todo las iglesias tuvieron la oportunidad de rescatar a las personas). Las autoridades exentaron a varios cientos de judíos de la deportación con base en sus servicios militares u otros méritos. En junio de 1944, el Ministerio del Interior ordenó la concentración de los judíos en Budapest, aproximadamente 220 mil, que vivían en dos mil casas marcadas con una estrella amarilla en varios distritos de la capital. Su situación mejoró inesperadamente cuando el 6 de julio, Horthy detuvo las deportaciones como resultado de los cambios en la situación militar y de las protestas internacionales.

"El nazismo todo lo dominaba y censuraba al Estado de Hungría. Estaba prohibido escuchar radio del extranjero, estaba penado recibir una que otra noticia y los periódicos estaban absolutamente bajo censura. Sólo lo que ellos quisieron que supiéramos, por ejemplo, que los gloriosos ejércitos que ya estaban, suponga usted, en Stalingrado y que aparecían 
luchando heroicamente, o sea que nunca nos dijeron que retrocedieron. Los alemanes llevaron al ejército húngaro adelante al igual que los rumanos y a otros ejércitos y los desangraron. Por eso precisamente el regente Horthy quería retirarse ya de la guerra, pero no lo dejaron, es cuando ocuparon toda Hungría los alemanes". (Entrevista Max Daniel Halpert, 2010).

"Nunca estuvimos en un gueto, nos metieron a mi mamá y a mí, a una prima y a una tía de mi mamá en un edificio de estrella amarilla donde juntaban a la gente antes de deportarlos. A mi padre lo habían enviado a campos de trabajos forzados, pero le daban permiso para regresar a vernos. Pudimos huir hacia otro edificio en uno de los bombardeos... Mi madre buscaba quien nos diera refugio...eran varios de los clientes de la joyería de mi abuelo que nos dejaban pasar la noche, pero a las cuatro o cinco de la mañana ya teníamos que estar en la calle. Nos quedamos hasta finalizar la guerra en una buhardilla”. (Entrevista a Eva Fainsod, 2010).

En agosto, la situación de los judíos mejoró cuando el general Géza Lakatos formó un nuevo gobierno. En octubre, los nazis ayudados por el Partido Cruz Flechada de Ferenc Szálasi tomaron el poder. Se lanzó de inmediato el terror contra los judíos y unidades de trabajos forzados fueron enviadas al oeste de Hungría. Continuos contingentes de judíos fueron enviados para trabajar al pie de los Alpes para la construcción de la línea de defensa contra los rusos durante el invierno de 1944-1945.

"En los trabajos forzados, formamos parte del primer grupo de defensa contra los ataques aéreos de Budapest. Entonces nosotros los judios 
tuvimos que salir, mientras los húngaros permanecían en el refugio. Teníamos que buscar gente, entonces no estaba uno acostumbrado, jalaba usted un brazo caliente y salía el puro brazo o una cabeza y mientras tanto caían las bombas alrededor de usted, era este el trabajo o, en su defecto, por ejemplo, habían bombas de los aliados defectuosas junto a las vías férreas, el suelo era bastante blando donde se enterraban entonces, teníamos que sacar las bombas con las manos para que vinieran los expertos a desactivarlas. Este fue el trabajo que nos dieron y desde luego ya no estábamos con Hungría, estábamos con los aliados, sabíamos muy bien que los nazis se apoderaron de Hungría”. (Entrevista Max Daniel Halpert, 2010).

Los judíos restantes en Budapest fueron divididos en dos grupos, a partir de mediados de noviembre, la mayoría fue trasladada al gueto central o grande, mientras que un grupo más pequeño encontró refugio en el llamado gueto internacional bajo la protección de los países neutrales.

Otro tipo de respuesta fue la de la resistencia organizada que no se logró alcanzar a gran escala. Una forma de la misma fue la actividad del movimiento de rescate de los sionistas (jalutzim), que proporcionó documentos falsos de identificación y ayudó a los necesitados con dinero, alimentos y ropa así como mediante el rescate de personas y su ocultación.

$$
\begin{aligned}
& \text { "Conocí a mi primer marido Peter Kallos }{ }^{18} \text { en esa época, cuando las leyes } \\
& \text { antisemitas prohibían que los judios estudiasen en las escuelas. Nos } \\
& \text { casamos en } 1944 \text { y es cuando, a los } 24 \text { años de edad sentí el verdadero }
\end{aligned}
$$

\footnotetext{
18 "Mi padre se contactó con la Resistencia, trabajaba con los partisanos como radio operardor e intérprete cuando las leyes antisemitas prohibían que los judíos estudiaran en las escuelas,". (Entrevista a Agnes Brawn y Peter Lang, 2010).
} 
peligro y valiéndome de mi audacia, conseguí papeles falsos para acudir a la clandestinidad en el momento necesario. Una nueva identidad como Irene Zagyva fue mi principal pasaporte. Yo había decidido resistir activamente, no esperar a que los enemigos hiciesen conmigo lo que quisieran. Mi madre que era una mujer muy inteligente, supo lo que venía y supo leer entre líneas, consiguió papeles de una chica cristiana y con eso me movía. Sobreviví, tuve que aprender toda la ascendencia de la chica de mis papeles. Cuando alguien nos denunció y vinieron les dije: sí aquí están mis papeles, los de mis papás y abuelos". (Entrevista a Agnes Brawn y Peter Lang, 2010).

A mediados de enero de 1945, además de algunas decenas de miles de judíos que se ocultaban con amigos, conocidos, o en apartamentos abandonados, había cerca de 70 mil personas en el gueto grande y cerca de 35 mil en el gueto internacional de Budapest. Desde el momento de la ruptura del poder de la Cruz Flechada hasta la ocupación rusa de la ciudad el 18 de enero de 1945, alrededor de 100 mil judíos de Budapest perdieron la vida en marchas de la muerte, transportes forzadas y asesinatos en masa. También por otras causas como epidemias, hambre, y suicidios. Alrededor de 825 mil a 850 mil ciudadanos húngaros considerados "judíos" (aproximadamente el 5.4\% de la población total), de entre ellos se estima que 565 mil fueron víctimas del Holocausto húngaro; 297 mil eran del territorio post-Trianon del país. Más del $40 \%$ de los judíos de Budapest y alrededor del 75\% de los judíos del campo perecieron.

El final de la guerra trajo consigo la liberación de los judíos, sin embargo los sentimientos antisemitas, que prevalecían desde tiempo antes, no desaparecieron en su totalidad debido en gran medida a la precaria situación económica. En 1946 hubo manifestaciones y ataques violentos en contra de los judíos en Kunmadaras y en Miskolc. La ley XXV de 1946, condenó todas las discriminaciones que habían sido introducidas 
contra los judíos y más tarde, la estabilización interna logró calmar los ánimos. (SzenteVarga, 2004).

Ante las disyuntivas que los gobiernos y la sociedad húngara dispusieron para adscribirlos en su identidad, las respuestas de los judíos como individuos y como judíos fueron ambivalentes y buscaron opciones de sobrevivencia: la asimilación, la resistencia, la ocultación o la muerte. La experiencia judía de la posguerra en el comunismo fue incierta. Para los judíos, el nuevo regimen comunista ofrecía una solución radical al "problema judío". Estos se enfrentaron a nuevos retos identitarios frente a las expectativas que ofrecía el comunismo y su concepción universalista. Una vez más una forma de asimilación fue solución para algunos. Aquellos que aceptaron el ofrecimiento, encontraron nuevas carreras en el sistema político, en la administración estatal y en el ejército, posiciones hasta ahora negadas para ellos. Los judíos activos en la elite del Partido Comunista, en palabras de Karady fueron caracterizados como "apparatchiks desjudaizados”. Sin embargo, quienes habían abrazado la causa del Partido Comunista y quienes asumieron nuevas posiciones en el régimen político de la posguerra fueron una minoría. La mayoría de los judíos, igual que el resto de la población, experimentaron una pérdida de sus medios de subsistencia como resultado de la nacionalización. Sin embargo, todos los judíos en Hungría fueron excluidos de su contacto con el pasado judío, Israel y el mundo de afuera. Específicamente la experiencia judía, especialmente la de la Shoá fue negada o ignorada y subsumida con la rúbrica general de "víctimas del fascismo". (Mars, L., 1999).

"Durante el gobierno fascista y los alemanes, mi madre y mi padre se hicieron fervientes comunistas. Cuando se estabilizó la situación se unieron al Partido Comunista, después vieron que era la misma porquería y se salieron del partido. Después mi padrastro tuvo roces con comisarios políticos, era doctor en Filosofía y Letras, lo expulsaron de la universidad, le prohibieron publicar y trabajó en lo que pudo, como obrero, donde encontrara algo de trabajo, hasta que le volvieron a dar permiso... Yo 
creo que una vez que empezó a perder la revolución temían que hubiera una purga. De hecho, sí la hubo, y a ellos les hubiera tocado”. (Entrevista a Agnes Brawn y Peter Lang, 2010).

Después de la Segunda Guerra Mundial, la Shoá y la creación del Estado de Israel en 1948, emergieron nuevos referentes identitarios que aparecen en las entrevistas.

"En agosto regresó mi hermano, con la rodilla enferma.... Todos regresaron vivos. No estuvimos en campos y dichosamente a mi mamá, mi padre la convenció de no salir. Ni mi padre ni yo estuvimos fuera de Hungría, en las fortificaciones alrededor de Budapest. Un año después de la guerra estuvimos sin trabajo, sin electricidad, sin gas, todavía diez años después había construcciones destruidas, en forma de cascajo. Fue un proceso lento. Dos años estuve en la preparatoria y algunos conocidos me metieron al movimiento juvenil Hashomer Hatzair, pero hay un dicho que más sabe el diablo por viejo que por sabio, tú sabes que hay un deseo en los niños y en los adolescentes de pertenencia, así que necesitaba esta pertenencia, los Scouts ya no, la mayoría murieron, la jefe murió, los jefes murieron así que ésta estuvo en lugar de los Scouts”. (Entrevista a Joel David, 2010).

“Al final, cuando terminé la preparatoria me presionaron y ya era el 47. Después de una intensa preparación para conseguir gente y armas, estuve en el grupo de húngaros que enviaron a Palestina, unas 20 muchachas y 20 muchachos. Pero cuando llegamos a Israel en el 48, cuatro meses 
después de la declaración de Independencia, no había campos de entrenamiento ni armas. En Israel nos encontramos con pura roca, no como la tierra suave de Hungría. Trabajamos con palas y picos". (Entrevista a Max Daniel Halpert, 2010).

\section{México, los judíos húngaros inmigrantes y sus referentes identitarios}

Los primeros inmigrantes judíos húngaros empiezan a llegar en el momento en que México vive también sus propios procesos de modernización. Los cambios y las transformaciones del proyecto político mexicano en el siglo XIX principios del XX, son producto de tres momentos fundacionales: la Independencia, la Reforma y la Revolución Mexicana, momentos que permitieron consolidar un nuevo tipo de nación basado en la unificación y en la construcción de una identidad nacional con el mestizo como figura medular.

Esto impactó en las políticas migratorias — formuladas desde los últimos años de la década de 1920 y principalmente en la de 1930 - que delimitaron el encuentro de los diversos tipos de inmigrantes con la sociedad nacional, al establecer los criterios que determinarían su entrada diferenciándolos por etnicidad, religión, razones económicas y otros parámetros que afectaron a varios grupos de inmigrantes, incluidos los judíos.

Cabe destacar que la Ley de Población de 1936 consideraba la aceptación sólo de aquellos extranjeros asimilables que ayudaran a "mejorar la raza mexicana". Definió los criterios de asimilación estableciendo cuotas diferenciales de inmigrantes en función del interés nacional, el grado de asimilación racial y cultural y la conveniencia de su admisión. Las tablas diferenciales muestran las restricciones de entrada de ciertos grupos (1938, 1939-40) tales como los judíos alemanes y austríacos, en comparación con la admisibilidad de los exiliados españoles republicanos que escaparon del franquismo. Sin embargo, entre los exiliados se encontraron judíos que habían participado en la Guerra Civil como voluntarios y se incluyeron a los exiliados españoles que entraron a México. Entre ellos, dos de los casos de este estudio. (va. Staropolsky, M., 2013). 
Según un estudio previo que se hizo sobre la migración húngara a México, entre 1901 y 1950, llegaron al país alrededor de tres mil húngaros, según las estimaciones de SzenteVarga (2004). Su número no fue muy significativo, pero se caracterizaron por su gran heterogeneidad en cuanto a los lugares de origen y condición social. De estos tres mil húngaros, más de la mitad eran judíos que se vieron forzados a salir por las condiciones antisemitas que culminaron con las leyes anti-judías impuestas desde 1920, así como las que se dieron en la década de 1930 y hasta finales de la Segunda Guerra Mundial y culminaron con el exterminio masivo de medio millón de judíos húngaros en mayo de 1944. Más de la mitad de los inmigrantes húngaro-judíos llegaron a México entre 1936 y 1950, algunos poco antes del estallido de la Segunda Guerra Mundial en 1939 y del exterminio masivo de judíos húngaros ocurrida en 1944, y otros al término de la Segunda Guerra Mundial (Szente- Varga: 2004) ${ }^{19}$.

De nuestro universo de estudio cualitativo, encontramos que veintiséis de los treinta y tres judíos húngaros que formaron parte de los casos del estudio llegaron a México entre el comienzo de los años veinte y fines de los cincuenta. Las más de treinta historias de vida del trabajo cualitativo sugieren que muchos llegaron de manera individual, otros en grupo familiar, pero la mayoría contaban con algún pariente que ya había llegado previamente y que se había establecido en México. La mayoría de los judíos húngaros entrevistados provenían originariamente de Budapest. Aunque no ofrecemos datos de esta llegada con precisión (individuo o familia) sólo queremos mostrar las tendencias de su proveniencia y años de llegada a México. De 1922 hasta 1932 se reportaron diez casos; durante el periodo de la Segunda Guerra Mundial, de 1936 a 1942 fueron seis los reportados; después de la Guerra, de 1946 a 1956 fueron diez y en 1974, uno proveniente de Israel. Entre los poblados y ciudades de origen más frecuentemente mencionados fueron Mád, Edelény y Sátoraljaújhely (provincia de Zemplén), Cluj (en la actual Rumania) y Miskolc (provincia de Borsod). También hubo quienes fueron originarios de Rumania, Checoslovaquia, Eslovaquia en territorios que, en algún momento pertenecieron al Imperio austrohúngaro y cuya lengua era el húngaro o magyar, además del alemán.

\footnotetext{
${ }^{19}$ México, en particular, se caracterizó por un doble movimiento, de apertura inicial y de cerrazón posterior, coincidente con las tendencias generales en el mundo (Bokser, L.J., 1999). 
“Mi tío, Maximiliano Frontenstein, vino acá después de la Primera Guerra Mundial, en 1922. Llegó a raíz del antisemitismo que surgió en Hungría después de la guerra. Fue médico de las mineras de Zacatecas donde se desempeñó exitosamente: inclusive hay un retrato de él en la Catedral de Aguascalientes porque le salvó la vida al Obispo. Posteriormente emigra a los Estados Unidos debido a la corrupción imperante en el país. Yo llegué en 1947”. (Entrevista Luis Stillman, 2009).

"Llegamos en 1956 a México en avión. Pasamos a Austria donde estuvimos cuatro meses, mientras mi tío nos arreglaba los papeles. Nos enviaron dinero y mis padres trabajaban en lo que se podía. Paramos en París, donde transbordamos a un avión más grande de cuatro motores con tres colas verticales, era único en su tipo. Viajó primero a Islandia para abastecerse, luego tuvimos que regresar porque uno de los motores andaba mal y finalmente, llegamos a México. Yo esperaba ver indios con arcos y flechas, pero llegué a una ciudad muy hermosa. Mi tío alquiló un departamento en un edificio viejo en Polanco y lo amuebló. Mientras el hijo expresó lo anterior, la madre intervino y comentó: “Estaba feliz, me integré. No vine a criticar, vine a vivir”. (Entrevista a Agnes Brawn y Peter Lang, 2010).

“Mi padre consiguió un visado para México. Primero llegó a Cuba, luego a México en el año de 1942. Ese año México le declaró la guerra a 
Alemania y él como húngaro queda como "extranjero enemigo amistoso" que tenía que reportarse ante la policía mexicana". (Entrevista a S. Czitrom, 2005).

De las treinta y tres historias de vida e historias familiares realizadas, hemos seleccionado catorce sujetos que son los que nos proporcionan con sus testimonios algunos referentes identitarios que han guiado esta narrativa, ejemplificando sus adscripciones, pertenencias e identidades. En el apartado anterior, las historias de vida nos ilustraron cómo el reordenamiento de los espacios geopolíticos operó como un factor determinante en la redefinición de esas adscripciones e identidades y se expresó en todo momento en decisiones de tipo pragmático. Estas decisiones se tomaron tanto por parte de la sociedad húngara como por parte de los judíos, ya fuera en su condición de individuos o como grupo minoritario. Ejemplo de ello fue la búsqueda de la asimilación, una respuesta necesaria y "deseada". Sin embargo, las resistencias de los grupos dirigentes y de la sociedad misma, operaron en su contra, desde la exclusión legal hasta la expulsión y más tarde a la aniquilación.

Estos individuos, que en sus relatos expresan sus sentimientos, sus cosmovisiones, sus actitudes frente a la vida y los acontecimientos vividos a través de sus trayectorias atestiguan esa diversidad, esos encuentros y desencuentros, nociones de arraigo y desarraigo, de esperanza y desesperanza en los inicios del siglo XX, en su llegada e inserción a México, inclusive recientemente.

En la época contemporánea la identidad judía se caracteriza por una multiplicidad de formas y de opciones de ser y de pertenecer, caracterizadas por su dinamicidad y fluidez lo que ha propiciado su complejidad. Esta complejidad se hace más densa al considerar que los individuos y grupos comunitarios judíos no están al margen de los procesos que se están dando en la mayoría de las sociedades en las que viven. Sin embargo, los judíos húngaros fueron el prototipo de la diferencia y de la otredad con sus particularidades en Hungría y esta condición permeó sus experiencias en su integración en los países de destino. Sociológicamente hablando, la distinción del "nosotros" y "ellos" señala que la pertenencia y la identificación con grupos concretos es una constante histórica e 
inevitable de Occidente y sin embargo, en su singularidad, este grupo muestra una faceta de contradicciones entre su deseo de ser igual y no diferente. Al llegar a México, nuevamente se subraya esta otredad y se les abre la puerta para su inserción.

En su trayectoria como migrantes y a su llegada, México, sería su lugar de incorporación y vinculación con el entorno como lugar residencia y permanencia. Una particularidad del grupo judío húngaro que pudo haber influido en su integración a México se refiere al carácter diferenciado del exterminio de los judíos húngaros con respecto a otros países europeos durante la Segunda Guerra Mundial. Mientras que en el resto de Europa las matanzas de judíos se iniciaron desde fines de de la década de 1930, en Hungría, la población judía permaneció casi completa hasta el mes de abril de 1944, cuando el fin de la guerra y la derrota del ejército nazi parecían cercanos. Excepcionalmente, en un lapso de apenas tres semanas (entre el 14 de mayo y el 8 de junio de 1944) más de la mitad de los judíos húngaros, cerca de 450 mil personas, fueron deportados a Auschwitz y en su mayoría asesinados. La responsabilidad compartida por invasores nazis, gobernantes y cuerpos armados húngaros y países occidentales aliados no evitaron este exterminio acelerado y masivo cuando la guerra se acercaba a su fin y esto puede haber influido en la reconfiguración de las identidades de los judíos húngaros que emigraron antes y después de estos hechos y que se asentaron en México (Fejto 1997, Braham 1973 y 1986, Kóvacs 1984). Sobre todo en términos de su relación, vinculación e identificación tanto con Hungría como con México y con la comunidad judía de México.

La mayoría de los inmigrantes judíos, entre ellos los húngaros, llegaron por diferentes circunstancias y para algunos el acceso fue más difícil y muestra que en las narrativas del pasado la identidad deja un dejo de añoranza y de vida.

"México es mi país porque yo llegué muy chica en 1929, aunque no he olvidado nada de Hungría porque ahí la pasé muy bien. He regresado dos o tres veces a Budapest". (Entrevista a Clara Forgacz, 2009). 
"Hice fortificaciones tanto en Hungría contra los alemanes e hice fortificaciones en Israel contra los árabes. En México ...mientras ... tengo tres hijos”. (Entrevista a Joel David, 2010).

"Desafortunadamente mi liberación no fue fácil. Hubiese sido diferente si me hubieran liberado los americanos o los aliados. Tuve que huir de un país a otro, entrar ilegalmente y hasta romper el pasaporte y quemarlo. Llegué a México (1949) y estuve escondido un año. No me fue fácil. Llegué sin permiso de trabajo, sin permiso para vivir”. (Entrevista Max Daniel Halpert, 2010).

Una mayoría de los entrevistados llegaron muy jóvenes, otros vivieron las constricciones del numerus clausus en Hungría, algunos llegaron adultos con o sin profesiones. En sus inserciones laborales muestran los cambios de oficios y cómo construyeron en el nuevo espacio sus nexos profesionales y ocupacionales de manera diferente. El desarrollo económico, social y cultural de la sociedad mexicana de las primeras décadas les permitió oportunidades de crecimiento económico, cultural, religioso, demográfico y de movilidad. Paralelamente la comunidad judía iba logrando construir espacios institucionales. La continuidad institucional como referente social y cultural fue básica como espacio de relación y vinculación identitaria para los judíos húngaros.

"Conseguí trabajo desde la primera semana de mi llegada en una librería y papelería. Tuve que aprender de papelería. Como no tenía papeles como psicóloga entré a trabajar después en una editorial, posteriormente como agente de ventas en la Enciclopedia Británica y fui gerente en una división de puras mujeres. Su hijo acotó: Fue la primera y la única, cerca de 1984, 
que se actualizó en Psicología y se dedicó de lleno a la misma". (Entrevista a Agnes Brawn y Peter Lang, 2010).

"El único documento que lo respaldaba era su título de arquitecto. Su primer trabajo fue la construcción de una iglesia en Huatusco, Veracruz. Posteriormente trabajó en la Compañía de Luz y Fuerza del Centro hasta su jubilación”. (Entrevista a S. Czitrom, 2005).

"De Europa venía con la idea de que sin instrumentos no hay trabajo. Me dediqué a componer la electricidad en la Colonia Condesa. Vivía con una tía y un día me hablaron. Era Alfonso Reyes y entré a una biblioteca enorme; trabajé una semana entera hasta que tuve el valor de hablar y preguntar ¿disculpe maestro usted leyó todos esos libros? Me respondió, Ni cincuenta vidas me alcanzarían para leer todos esos libros, yo los necesito para consulta. Le comenté que quería estudiar computación para tener una biblioteca como esa. Guardo gratos recuerdos, aunque en esa época yo hablaba el español peor que hoy". (Entrevista a Max Daniel Halpert, 2010).

Si la identidad es ser y pertenecer, ser judío tiene implicaciones étnicas y posturas de religiosidad y pertenecer ser parte de una comunidad, de un grupo. Esta dimensión está relacionada con los cambios que ocurrieron en Europa a fin de transitar del mundo religioso tradicional al moderno y participar en las redes de asociación predominantemente judías. En los judíos húngaros se manifestó en una multiplicidad de opciones de ser judío que incluyó elementos de universalismo y de particularismo; de exclusión e inclusión, relacionados con la otredad; de continuidad o de ruptura en función 
del progreso y de la secularización, de los valores de la vida, pero también en la búsqueda de nuevas formas de garantizar la continuidad grupal como judíos.

En México, desde su llegada en diferentes periodos la identidad se manifestó en una diversidad de vínculos primordialmente familiares, que destacan una mayor atención a las tradiciones, donde el valor y la importancia del ritual se prioriza sobre su contenido religioso primario. La pertenencia y la partición grupal voluntaria, no adscrita, adquiere mayor relevancia. Como parte del grupo judío, se insertaron en el contexto de una sociedad mayoritaria, con la que establecieron vínculos como sucedió con otras minorías. La identidad étnica manifiesta se mantiene siempre que subsista la diferenciación entre los ámbitos, los valores y símbolos propios respecto a los ajenos ${ }^{20}$.

¿De qué manera se vieron afectados en sus identidades los judíos húngaros que llegaron a México? ¿Operó éste como un espacio de cambio y de transformación en sus identidades?

Desde que llegaron a México se relacionaron con la comunidad Ashkenazí ${ }^{21}$ (judíos provenientes de Europa Oriental y Occidental). La diferenciación organizativa se manifestó en el surgimiento de instituciones diversificadas incluyendo también asociaciones regionales de los judíos de Europa Central. Hasta fines de los años treinta e incluso algo después, los judíos húngaros habían actuado en el seno del Club AustroHúngaro de México, pero a raíz del auge del nazismo en Europa decidieron formar su propia organización. En 1938 se organizaron en el Club Zión que, a partir de 1942 se consolidó como Emuná. (Bokser, L.J. et.al. 1992).

Emuná operó como recinto de interacción social y cultural. En el testimonio de Clara Forgacz (2009) deja constancia que al separarse del Club Austro- Húngaro de México,

\footnotetext{
20 "Un individuo determinado puede interactuar con otros en nombre propio o en cuanto miembro o representante de uno de sus grupos de pertenencia. Comparte elementos centrales de la identidad -como la capacidad de distinguirse o ser distinguido de otros grupos, definir los propios límites, generar símbolos y representaciones sociales especificos y distintivos, configurar y reconfigurar el pasado del grupo como una memoria colectiva e incluso de reconocer ciertos atributos como propios y característicos - sujeto grupo, sujeto actor colectivo". (Giménez G., 1997).

${ }^{21}$ La comunidad judía de México, desde sus inicios hasta hoy en día, se caracteriza por estar conformada institucionalmente por una diversidad de sectores subétnicos: Ashkenazí, Sefaradí, Maguen David y Monte Sinaí y por sectores religiosos y comunitarios ortodoxos y conservadores.
} 
por la entrada del nazismo, se hizo un club a nombre de Santa Isabel de Hungría y otro para los judíos. "Pero el club Húngaro era más divertido porque hacían obras de teatro húngaras y llegué a participar en las mismas, hacíamos recitaciones patrióticas el 15 de marzo y vivíamos una vida con más identidad húngara”. Sin embargo, para algunos entrevistados fue, además un referente social donde los jóvenes se conocían y se relacionaban.

“Cuando mis padres llegaron a México en 1930, mi papá había terminado para ser rabino y había estudiado también en Frankfurt para lo mismo. pero no pudo seguir por toda la cuestión antisemita. Era un hombre muy preparado y muy inteligente que luego que se convirtió en el presidente de la comunidad judía húngara que se llamaba Emuna. Él la presidió por muchos años cuando estuvo ubicada en Puebla 212”. (Erika Mogyoros, 2012).

“Todos crecimos yendo al Club Húngaro pues los judíos húngaros se reunían allí. Primero era Hungría Libre, donde iban judíos y no judíos, después se separan los judíos y forman su propio club Emuná. Ahí se reunían para tener pláticas, clases, conferencias, bailes, jugaban barajas y hacían cenas, toda la vida social de los judios húngaros. Al judio húngaro le interesaba mucho la cuestión social. Emuná era el foco social de los judios húngaros, era muy importante. Que yo conozca no creo que haya un grupo tan unido alrededor de lo que fueron sus raíces. ya que realmente el judío húngaro, en especial, es muy sociable”. (Erika Mogyoros, 2012). 
La pertenencia atraviesa otros espacios intercomunitarios como ser miembro del Centro Deportivo Israelita —institución dedicada al deporte, a la cultura, a lo social y a fortalecer principalmente los lazos entre los diversos sectores subétnicos-al ofrecer una membresía con mayor accesibilidad.

La diversificación institucional es una particularidad de la comunidad judío mexicana que muestra una diferencia de pertenencias y los judíos húngaros se insertaron en las mismas. Pocos de los entrevistados mencionaron sus afiliaciones juveniles en Hungría, alguno señaló su pertenencia a los Scouts o a una tnuá (movimiento juvenil) o ser parte del coro del templo. En México el vínculo comunitario se incrementó en otro sentido desde la llegada: en la necesidad de sentirse parte de...en una sociedad donde la religión, el idioma, la cultura, era totalmente diferente.

Un ejemplo de pertenencia reciente es el de Peter Lang, nacido en 1945 en Budapest hijo de Agnes Brawn:

"Pertenezco a la Kehilá Ashkenazí, soy miembro del CDI, pero no voy al templo en las fiestas. Mi mamá nunca celebró nada, aunque nosotros sí celebramos las fiestas en casa. Soy un hombre creyente pero no religioso. No me gusta que me estructuren la forma para dirigirme a Dios y tener que hacerlo de una forma determinada". (Entrevista Agnes Brawn y Peter Lang, 2010).

Respecto a los sentimientos — creencias y prácticas religiosas — los testimonios reflejan una transición del judaísmo tradicional al judaísmo moderno. De la religiosidad a la secularización, una transición mediada por los entornos donde vivieron esas experiencias, tanto en Hungría como en México, donde se combina y se mezcla la religiosidad, como práctica con los vínculos con la comunidad judía y con el Estado de Israel. Donde prevalecen a veces las experiencias de estigmatización y discriminación, pero también 
donde se juegan las identidades construidas o elegidas, que se expresan de manera distinta en diferentes etapas de la vida.

“Hablábamos de la identidad y de lo que la gente siente ¡Cuántas etapas pasan por una vida! ¿Cómo pude ser un hombre tan religioso que a diario rezaba en la mañana, tarde y noche? Desde luego me ponía tefilin (filacterias) desde los trece años, era un orgullo para uno ponérselos. En 1947, cuando pude salir de Hungría viví en Italia hasta 1948 porque no podían arreglarme los papeles de entrada aquí, en ese año nació el Estado de Israel. Entonces me dijeron vete a Israel, ya tenemos país; no me da vergüenza decirle que yo de guerras ya no quiero saber nada. Como no era un sionista devoto, era joven y fuerte y ya me había recuperado les dije que tenía parientes en México. Me hubiera tocado ir al ejército y no quería tanto militarismo”. (Entrevista a Max Daniel Halpert, 2010).

"Mis padres siempre se sintieron como extranjeros, ya no pertenecían a Hungría pero no se sentían mexicanos, más bien su amor era hacia Israel, eran muy sionistas, nos educaron como sionistas. Siempre hubo la sensación de que estaban de paso en México, nunca hubo la pertenencia de interesarse, de luchar, de hacer algo, más en especial por México, siempre se conservaron en su núcleo húngaro social y de trabajo, era un ambiente de todos los judíos húngaros”. (Entrevista a Erika Mogyoros, 2012). 
"La religión y sus tontas restricciones que guardan los judios como pueblo. Estoy seguro que esta visión histórica fue inventada desde Moisés y Aarón para guardar al pueblo como pueblo unificado... Si hay Dios, es uno. En mi opinión el que el pueblo judío seamos el pueblo escogido es absolutamente una visión chauvinista ¿Y por qué? ¿podemos ser nosotros el pueblo de los amos del mundo? Las persecuciones me hacen más judío que la religión y ser parte de una minoría perseguida, me hace más judío. Me siento judío más por solidaridad de los oprimidos. Aunque fui a la Hashomer Hatzair, estuve en el Kibutz, y todo eso de que Dios no existe, hoy veo la cosas con una luz diferente”. (Entrevista a Joel David, 2010).

"En cuanto a la religiosidad actual soy tradicionalista totalmente. Les di educación a mis hijos según mi convencimiento, mis raíces y los mandé a una escuela judía. Guardamos todas las fiestas. En lugar de contarles cuentos les platicaba la Biblia en español y les contaba de ahí las historias... Hay ciertos cambios en mi vida, en estos momentos soy agnóstico, soy y me siento muy buen judío, pero no sigo la ortodoxia. Sigo siéndolo dentro de mí, dentro de mi alma y sin embargo, siempre me ha gustado mucho la ciencia. Soy tolerante a más no poder, respeto al judío religioso como al ateo. Cada quien según su convencimiento y su sentir". (Entrevista a Max David Halpert, 2010). 
"Si te preguntaban si eras judío, contestabas que sí, pero nunca hacías ostentación, no llevamos vida religiosa ni comunitaria judía. Mi madre decidió ser atea en esa época y me criaron así, aunque no le salió muy bien, yo tenía problemas en la escuela por ser judío. Después de salir de Hungría no he vuelto a tener ese problema en México. En una ocasión unos muchachos me molestaron y insultaron y ya eso fue todo". (Entrevista a Peter Lang, 2010).

Las convergencias, divergencias y conflicto entre diferentes identidades en los testimonios nos ofrecen esa combinación de referentes y factores que inciden en las mismas.

"No niego mi entusiasmo por México, por cómo me recibió. Mi esposa era mexicana, mis hijos son mexicanos. No estoy de acuerdo con la política, aunque ¡lástima que cuando Moisés salió de Egipto no encontró este país! Yo era un ciudadano orgulloso en Hungría. Ya no, los húngaros, en general, son muy húngaros. No tengo resentimiento contra Hungría ya que también siento una identidad con el país. Me da gusto cada logro, algún día los aceptarán en la Unión Europea pero, ¿sabe? me dan más gusto las noticias de Israel”. (Entrevista con Max David Halpert, 2010).

"Mis papás nunca hubieran querido que yo fuera a una escuela judía porque decían que en el mundo somos los menos. Toda la demás gente es más, entonces no tiene caso encerrarse en un grupito cuando estás viviendo en un país que no es judío. Tú tienes que sentirse como los 
demás, pero sabiendo que tú eres judía. Esto era en automático, así crecimos, mis padres no eran muy religiosos, pero sí conservadores, en las fiestas, en todas las cosas y las oraciones se las sabían cantadas, pero no creo que lo hacian en plan religioso”. (Entrevista a Clara Forgacz, 2009).

Pero las persistencias controvertidas con los vínculos del pasado están presentes en todo momento. Como señala Luis Eduardo Feher (2010) respecto a lo que sus padres sentían por Hungría: "Ellos guardan el sentimiento de antes del nazismo: el recuerdo agradable, la nostalgia grata, por eso van a la Embajada húngara cuando se celebra el día de la Independencia, a encontrarse con sus raíces".

"Yo creci en un ambiente donde había mucha nostalgia por Hungría, su comida, su folklore, todo el tiempo mi mamá recitaba poesía en húngaro, de cuando era niña. Mis tíos cuando se juntaban cantaban las canciones de su adolescencia cuando se encontraban allá, inclusive había canciones traducidas del hebreo al húngaro. Por ejemplo, el Hatikvá, yo lo sé en húngaro porque así se cantaba y muchas canciones del Palmaj se cantaban en húngaro así que había mucha identificación con Israel, sobre todo eran muy sionistas. Eran, los judios húngaros, que siempre hablaban que algún día se irían a vivir a Israel, pero recordaban su época de la infancia, cuando nadaban en el río del pueblo y las travesuras que hacían y cómo se reunían los jóvenes. Entonces, sí había mucho arraigo a su origen, a toda la parte húngara. Todo el tiempo hablaban de lo que hacían cuando eran jóvenes, cuando se conocieron, de las comidas, de los abuelos, siempre había un regreso, una nostalgia a lo que significaba ser húngaro”. (Entrevista a Erika Mogyoros, 2012). 
“El himno húngaro lo cantábamos precioso y era para mi el más bonito. Me gustó mucho desde niño por su letra. No era agresivo: "Dios bendiga al húngaro, con buen humor y abundancia...Actualmente soy mexicano y me sé el himno, pero el anterior me dejó huella toda la vida y a quién si no si lo canta uno quinientas veces, el buen humor y la abundancia”. (Entrevista Max Daniel Halpert, 2010).

"Cuando me preparé para esta entrevista me quedé pensando ¡no sé cómo sobreviví en Hungría! Mi vida era peligrosa, era muy rebelde, no me sometía, todo lo que hacía era peligroso". (falsificación de documentos) "Era mucha rebeldía y mucho enojo por la persecución. Guerra quieres y guerra tendrás" (Entrevista a Agnes Brawn, 2010).

En cuanto al magyar, húngaro como lengua materna, su cultura y otras lenguas, es importante señalar que esta operó como el vínculo de ser y de pertenencia para la mayoría de los judíos húngaros. La internalización de la cultura magyar operó como una forma de conexión en su sentir nacional, ser parte de... y que tuvo que ser replanteada ante las nuevas circunstancias que les ofreció México como espacio de vida y de desarrollo.

"Sobre mi identidad no sé qué responder. No me puedo identificar con Israel: chauvinista, nacionalista ni con los ultra religiosos, que por su extremismo no puede haber paz. Los judios húngaros son diversos: neólogos, ortodoxos y ultraortodoxos. Nosotros éramos húngaros de religión judía. Nosotros éramos húngaros, punto. Como hay católicos y protestantes. Además, el idioma húngaro, muy pocos lo saben, es 
extraordinariamente rico y bonito, para la palabra correr, caminar existen ciento ocho sinónimos que se usan cotidianamente. El húngaro es riquísimo, no hay géneros, y culturalmente cada noche en la ópera de Budapest, hay dos eventos cada noche y está lleno de gente”. (Entrevista a Joel David, 2010).

"Con respecto a mi identidad como mexicana, hay un aspecto que me molestaba mucho, porque el húngaro tiene un acento no hay idioma donde no aparezca. Y siempre me decían Tú no eres mexicana y me daba un coraje, pues yo quería ser mexicana. Ahora ya me vale, ya recuperé mi nacionalidad húngara, mis hijos son húngaros, mis nietos son húngaros, pero por conveniencia. ¿Que por lo menos algo que les pueda sacar después de todo lo que me hicieron!'”. (Entrevista Eva Fainsod, 2010).

"Hablaban húngaro hasta..., siempre hablaban húngaro entre ellos. En los últimos años ya hablaban en español pero siempre se hablaba en húngaro. Mi mamá estudió alemán, ya ves que en Budapest hablaban en alemán. Había una influencia alemana en la Hungría bárbara. Mi papá no estudió, pero en casa de mi papá no se hablaba idish”. (Entrevista a Víctor Miklos, 2010).

“Con mis tíos hablé con ellos en húngaro. Desde que se murió mi última tía de Hungría, no hablo con nadie en húngaro. La verdad es que, aunque 
no lo practico no se olvida porque, por ejemplo, hacer cualquier tarea matemática solamente la hago en húngaro. Aunque pienso en español, con los números lo hago en húngaro". (Entrevista a Max David Halpert, 2010).

"Al principio sólo hablábamos húngaro luego español. Con mi esposa hablamos español, pero cuando la familia se reunía hablábamos húngaro, entonces ella empezó a entenderlo". (Entrevista a Agnes Brawn y Peter Lang, 2010)

\section{Algunas reflexiones}

Los judíos húngaros se vieron confrontados en sus identidades ante los desafíos de la modernidad en Hungría, en todo momento. Una modernidad que, en su caso, tuvieron que vivir en una sociedad, donde para ser ciudadano tenían que ir adaptando y adoptando las diferentes definiciones que la misma les otorgaba como judíos, como israelitas, como judíos denominados o reconocidos con el fin de incorporarse o pertenecer a ella en un permanente dilema. Las paradojas y las contradicciones aparecen a lo largo del texto ya que la asimilación operó como el acicate de ese deseo acucioso de su pertenencia en una sociedad donde la supervivencia y la movilidad judías eran, por una parte, en ciertas condiciones, fluidas y por la otra cada vez más difíciles y complicadas. Es asombroso que, aún existiendo judíos ortodoxos, el deseo y el sentimiento de ser húngaro prevalece hoy en aquellos inmigrantes que aún pudimos entrevistar y, que en parte se lo transmitieron a sus hijos a través de un elemento en común: la lengua magyar, el húngaro. Varias entrevistadas nos expresaron que cuando se reúnen los judíos húngaros, no importa quiénes estén con ellos, llevan a cabo la conversación en húngaro, aunque los demás no lo entiendan. 
Este artículo presenta los contrastes entre la diversidad cultural en el contexto húngaro y quizás en menor grado en México, donde los inmigrantes, a pesar de su extranjería, no vivieron procesos de estigmatización ni de discriminación. Cabe señalar que su inserción en México estuvo mediada por dos tendencias que no fueron expresamente planteadas: hubo quienes se asimilaron, no sólo que se casaron con personas no judías, sino que rompieron todo tipo de lazos de identificación y pertenencia comunitaria; pero predominaron aquellos inmigrantes y sus descendientes que reforzaron su identificación como judíos húngaros, parte de la Comunidad judía mexicana con diferentes grados de integración con la sociedad mayoritaria.

Quizás es importante reflexionar acerca del papel de la lengua húngara en el contexto mexicano, que hizo que, a pesar de todas las diferenciaciones de religiosidad, ésta haya sido un medio de comunicarse de manera distintiva que sumado a los constantes viajes en busca de paisajes recreados en el pasado, o en la búsqueda de sus raíces que casi todos los judíos húngaros y sus familias han hecho varias veces a Hungría.

A pesar de que el grueso de la inmigración de judíos húngaros a México se produjo en etapas donde también este país estaba en la construcción y consolidación de una identidad nacional basada en nociones de homogeneidad cultural y étnica, algunos factores favorecieron la ausencia de procesos de estigmatización y discriminación hacia el grupo judío mexicano de origen húngaro. Entre ellos destacan la expansión de sectores medios e intelectuales en la sociedad mexicana en los periodos de arribo de la inmigración húngara (años treinta a sesenta del siglo XX), la existencia previa de una comunidad judía organizada en la ciudad de México y el origen europeo y mayoritariamente urbano de los inmigrantes húngaros. Es posible que también hayan contribuido a la heterogeneidad cultural de la sociedad mexicana (que facilita la aceptación de diversidades) y a la valoración social positiva que se otorga en México a los representantes de grupos europeos y a la cultura moderna. Desde sus variaciones identitarias, sus referentes como judíos provenientes de Hungría son hoy la familia, la pertenencia comunitaria, el Estado de Israel y una añoranza por esa Hungría que fue... donde quisieron ser y no se les permitió ser. 


\section{Bibliografía}

Baron, S. (1983). Nuevos enfoques acerca de la Emancipación Judía. En David Bankier

(Ed.) La Emancipación Judía. Antología de artículos en perspectiva histórica. Jerusalem: Magnes Press The Hebrew University.

Bokser L., J. (2013). Encuentros, dilemas y proyectos en la historia: Modernidad y Movimiento Nacional Judío. En Meyer, J. (Dir.) ISTOR Publicación trimestral de la División de Historia del Centro de Investigación y Docencia Económicas (CIDE), año xiv, número 55, invierno de 2013. Internet: $\underline{\text { www.istor.cide.edu }}$

Bokser L., J. et.al. (1992). Imágenes de un Encuentro. La Presencia judía en México durante la Primera Mitad del Siglo XX. México: UNAM, Tribuna Israelita.

Czitrom, V.; Czitrom, S.; Czitrom, P. (2001). Carolyn y Laszlo ¡Qué vida!. The Baus, Feuerstein, Czitrom and Lusztig Families. Florencia,México.

Deak, I. (1983). Assimilation and Nationalism in East Central Europe During The Last Century of Habsburg Rule. The Carl Beck Papers in Russian And East European Studies, NTS, Paper No.202. Citado en Goldstein, D. M. (1995). De la Estrella Amarilla a la Estrella Roja: el Antisemitismo, el Anticomunismo y los judíos en Hungría. Política y Cultura, primavera, número 004. México: Universidad Autónoma MetropolitanaXochimilco (polcul@correo.xoc.uam.mx) redalyc Universidad Autónoma del Estado de México http://redalyc.uaemex.mx 
DellaPergola S., Lerner, S. (1995). La población judía de México: perfil demográfico, social y cultural. México: Universidad Hebrea de Jerusalén, COLMEX y Asociación Mexicana de Amigos de la Universidad Hebrea de Jerusalén.

Fejtö, F. (1997). Hongrois et Juifs. Histoire millénaire d’un couple singulier (1000-1997). Contributions à l'étude de l'integration e du rejet. Paris: Éditions Balland.

Giménez, G. (1993). Cambios de identidad y cambios de profesión religiosa. En Bonfil, G. (Coord.) Nuevas Identidades Culturales en México, México: CONACULTA.

Goldstein, D. M. (1995). De la Estrella Amarilla a la Estrella Roja: el Antisemitismo, el Anticomunismo y los judíos en Hungría. Política y Cultura, primavera, número 004. México: Universidad Autónoma Metropolitana- Xochimilco (polcul@correo.xoc.uam.mx) redalyc Universidad Autónoma del Estado de México http://redalyc.uaemex.mx

Haraszti, G. (2010). En Hungary: Hungary from 1918 to 1945. YIVO Encyclopedia of Jews in Eastern Europe. Retrieved September 2, 2016, from http://www.yivoencyclopedia.org/article.aspx/Hungary/Hungary_from_1918_to_1945.

Karády, V. (1992).Antisemitisme et stratégies d’integration citado en Mars, L. (1999) Discontinuity, Tradition, and Innovation: Anthropological Reflections on Jewish Identity in Contemporary Hungary. En Social Compass March 46: 21-33 
Katz, J. (1977). “The Uniqueness of Hungarian Jewry". Forum 45-53. En Kóvacs, A.

(2013). Jews and Jewishness in Post-war Hungary .

http://www.osservatorioantisemitismo.it/wp-

content/uploads/2013/03/quest_kovacs_antisem-in-hungary.pdf

Kovács, A. (2010) Jews and Jewishness in post-war Hungar. En Quest. Issues in Contemporary History. Journal of the Fondazione CDEC, n. 1, URL http://www.questcdecjournal.it/focus.php?issue=1\&id=192

Kovács, A. (1997). Jewish Assimilation and Jewish Politics in Modern Hungary http://web.ceu.hu/jewishstudies/pdf/01_kovacs.pdf

Liwerant, J. (2006). Semitas en el Espacio Público Mexicano, en Klich, I.(Comp.) Árabes y judíos en América Latina. Historia, representaciones y desafíos. Buenos Aires: Siglo XXI Editora Iberoamericana.

Mars, L. (1999) Discontinuity, Tradition, and Innovation: Anthropological Reflections on Jewish Identity in Contemporary Hungary. En Social Compass March 46: 21-33

Mendelsohn, E. (1983). Los Judíos de Europa del Este Central, entre las guerras mundiales, Bloomington: Indiana University Press citado En Kovács,A. (2010) Jews and Jewishness in post-war Hungary En Quest. Issues in Contemporary History. Journal of the Fondazione CDEC, n. 1, URL. 
Moreno M., C. (2015). Breve historia del Imperio Austro-húngaro Madrid: Ediciones Nautilus, (Colección: Breve Historia www.brevehistoria.com)

Pérez, C. (1994). La experiencia revolucionaria húngara 1918- 1939 http://www.belliludi.com/ludo/exp_hungara.pdfö̈s]

Sabido R., O. (2012). Tres miradas sociológicas ante el extrañamiento del mundo. En Introducción en el Extranjero. Sociología del Extraño. George Simmel, Alfred Schütz, Norbert Elias y Massimo Cacciari. Madrid: Ed.Sequitur.es

Silber, M. K. (2010, August 26). Hungary: Hungary before 1918. YIVO Encyclopedia of Jews in Eastern Europe. Retrieved September 5, 2016, from http://www.yivoencyclopedia.org/article.aspx/Hungary/Hungary_before_1918.

Staropolsky, M.(2013). La presencia judía en el Exilio Español en México. Tesis Maestría en Estudios Judaicos, México: Universidad Hebraica

Stuart, H. (2013). En Whitfield, S. Enigmas of Modern Jewish Identity, Jewish Social Studies. Vol.8. No. 2/3, Winter/Spring 2002. Project MUSE. The Johns Hopkins University Press

Szente, Varga, M. (2004). Migración Húngara a México entre 1901 y 1950. Tesis de Doctorado. Hungría: Szeged 
Szente Varga,M. (2008). Inmigrantes húngaros en México y la formación de una colonia húngara. En Dimensión Antropológica, Año 15, Vol43, Mayo/Agosto, 2008.)

The YIVO Encyclopedia of Jews in Eastern Europe (2008). Two-volume, Englishlanguage reference work on the history and culture of Eastern Europe Jewry, prepared by the YIVO Institute for Jewish Research and published by Yale University Press.

Zaga M.,S. ,Cohen C.,E. (Dir. y Coord.) (2002). El Rostro de la Verdad. Testimonios de Sobrevivientes del Holocausto que llegaron a México. Colombia: Memoria y Tolerancia

\section{Relación de entrevistas.}

- Brawn, Agnes e hijo Peter Lang, entrevista realizada el 8 de febrero de 2010 por F.

Cassab y F. Staropolsky

- Czitrom, Steven sobre Lazlo Czitrom, entrevista realizada el 19 de diciembre 2005 por

I. Szasz

- Daniel Halpert, Max, entrevista realizada en el 2010 por M. Taifeld y F. Staropolsky

- David, Joel, entrevista realizada en 11 de julio de 2010 por F. Staropolsky

- Fainsod, Eva, entrevistada realizada el 18 de enero de 2010 por A. Faena y F. Staropolsky

- Feher, Luis Eduardo, entrevista realizada el 11 de febrero de 2010 por A. Faena y F. Staropolsky

- Forgacz, Clara, entrevista realizada el 14 de diciembre de 2009 por F. Cassab y F.

Staropolsky 
- Goldstein, Eva, entrevista realizada en 2010 por A. Faena

- Klein, Violeta, entrevista realizada en 2008 por I. Szasz y F. Staropolsky

- Mogyoros, Erika, entrevista realizada el 31 de enero de 2012 por F. Staropolsky

- Miklos, Víctor, entrevista realizada el 16 de enero de 2010 por F. Staropolsky

- Stillman, Buba, entrevista realizada el 14 de octubre de 2009 por F. Staropolsky

- Stillman, Luis, entrevista realizada el 15 de diciembre de 2009 por M. Taifeld y F.

Staropolsky 